
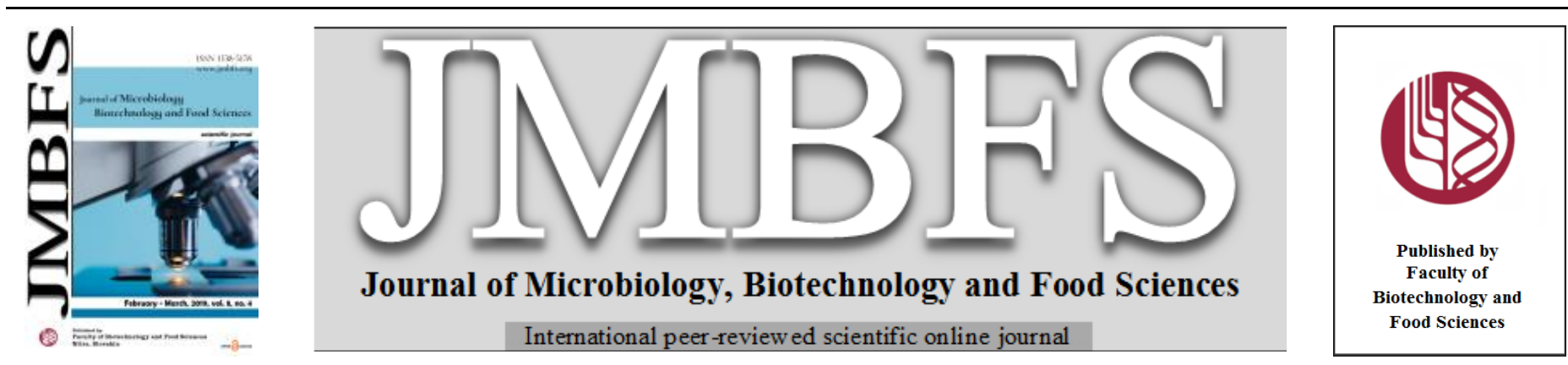

\title{
ISOLATION AND CHARACTERIZATION OF L. parafarraginis (KU495926) INHIBITING MULTIDRUG-RESISTANT AND EXTENDED SPECTRUM BETA-LACTAMASE GRAM-NEGATIVE BACTERIA
}

\author{
Rachelle Allen-McFarlane ${ }^{1}$, Adrian Douglas Allen ${ }^{1}$, Garima Bansal ${ }^{1}$, Broderick Eribo* \\ Address(es): Ph.D. Broderick Eribo, \\ ${ }^{1}$ Howard University, Department of Biology, 415 College St. NW., 20059, Washington D.C., 202-806-693.
}

*Corresponding author: beribo@howard.edu

doi: 10.15414/jmbfs.2019.8.4.1041-1053

\section{ARTICLE INFO}

Received 11.8.2018

Revised 5. 11. 2018

Accepted 12. 11. 2018

Published 1. 2. 2019

Regular article

open $\partial_{\text {Access }}$

\begin{abstract}
A new strain of Lactobacillus parafarraginis was isolated from a sample of commercial yogurt and identified by phenotypic and molecular methods. Phenotypic characterization showed bacilli sizes $\sim 0.75-2.75 \mu \mathrm{m} \times 0.25-0.75 \mu \mathrm{m}$, a generation time of $\sim 3.04 \mathrm{~h}$ under anaerobic conditions, halotolerance, lactose fermentation, production of hydrogen sulfide gas from Kliger iron agar, and the presence of an unusual fatty-acid methyl ester, cis- 10-nonadecenoic acid. Based on 16S rRNA gene sequencing, the isolate was identified as Lactobacillus parafarraginis and given the GenBank accession number (KU495926). L. parafarraginis (KU495926)) inhibited 14 multidrug-resistant (MDR) and extended spectrum $\beta$-lactamase (ESBL) Gram-negative clinical isolates, as well as 11 other pathogens by spot-test and well-diffusion assays. The MDR/ESBL clinical isolates and other pathogens included Escherichia coli, Pseudomonas aeruginosa, Acinetobacter baumannii/haemolyticus, Enterobacter aerogenes, Proteus mirabilis and Klebsiella pneumonia, Staphylococcus aureus, Listeria monocytogenes, Escherichia coli (O157:H7), Bacillus cereus, Yersinia enterocolitica, Pseudomonas aeruginosa, Shigella sonnei, Streptococcus pyogenes and Enterococcus faecalis. Analyses of the semi-purified inhibitory fraction by SDS-PAGE, fast perfusion liquid chromatography (FPLC) inferred antimicrobial properties, characteristic of bacteriocins, with a protein band of $\sim 75 \mathrm{kDa}$. Four bacteriocin structural genes which include sakT- $\beta$ for sakacinT- $\beta$ chain, sakT- $\alpha$ (sakacinT- $\alpha$ chain), acd T (acidocin), and plnc8A (plantaricin- $\alpha$ chain) were detected by PCR. The data suggest that $L$. parafarraginis (KU495926) may be a novel strain with potential therapeutic application. To our knowledge, this is the first report of the isolation of this strain from yogurt.
\end{abstract}

Keywords: Lactobacillus parafarraginis, lactic acid bacteria (LAB), multi-drug resistant (MDR), extended spectrum beta-lactamase (ESBL), bacteriocin

\section{INTRODUCTION}

The genus Lactobacillus, first proposed by Beijerinick (1901) (Lin et al., 2013), consists of phylogenetically diverse (224 species and 29 subspecies) organisms known as lactic acid bacteria (LAB) (http://www.bacterio.net/lactobacillus.html). The commonality among these organisms is the fermentation of carbohydrates to produce lactic acid as the sole or main end product (Tannock, 2004). Having been used by humans since time immemorial for fermented food production and preservation, LAB are generally recognized as safe (GRAS)(Ongol, 2012). Lactobacilli, although widely distributed in the environment (Holt et al., 1994; Jay et al., 2008), are fastidious, having complex nutritional requirements of amino acids, peptides, vitamins, peptides, vitamins, salts, fatty acids, fatty acid esters and nucleic acid derivatives (Moretro et al., 1998; Salvetti et al., 2012; Tannock, 2004). Their complex nutritional requirements are often reflective of their habitat where carbohydrate containing substrates are available (Salvetti $\boldsymbol{e}$ al., 2012). They may be homofermenters - fermenting hexoses almost exclusively $(>85 \%)$ to lactic acid with pentoses and gluconates are not fermented; facultative heterofermenters - fermenting hexoses to lactic acid and degrade pentoses and gluconates to acetic acid, ethanol and formic acid under conditions of limited glucose or obligate heterofermenters - metabolize pentoses and hexoses to produce lactic acid, ethanol (or acetic acid) and carbon dioxide (Salvetti et al., 2012). Additionally, some lactobacilli are known to produce exopolysaccharides which contribute to the texture of foods and in their survival as probiotics in the gastrointestinal tract (Badel et al., 2011; Sun et al., 2015).

The first species of $L$. parafarraginis, reported by Endo and Okada in 2007, was isolated from a compost of distilled shochu (a traditional Japanese distilled spirit made from rice, sweet potato, barley or other starchy nutrients) residue (Endo and Okada, 2007). Increasing research on L. parafarraginis has identified strains capable of improving aerobic stability of silage (Liu et al., 2014); deodorization and purification of water in eel farming (H. H. Lee et al., 2013); and metabolizing lactic acid anaerobically (Johanningsmeier, 2011). The efficacy of LAB, as a bio-control may lie in its gene products such as bacteriocins. Bacteriocins, discovered by the Belgian scientist Andrè Gratia in 1925 (Daw and Falkiner, 1996), are among the most important antimicrobial agents produced by LAB. They are diverse and naturally abundant ribosomally synthesized antimicrobial peptides, polypeptide, proteins or protein complexes which have been found in all major lineage of Bacteria and Archaea (Klaenhammer, 1988; Parada et al., 2007; M. Riley and Gillor, 2007; Zacharof and Lovitt, 2012). They are usually produced during stressful conditions, released extracellularly, utilized during competition for space and nutrients by rapid eliminating neighboring cells that are not immune to their effect (Heng et al., 2007; Pingitore et al., 2007; M. A. Riley and Gordon, 1999).

Over the years, interest in bacteriocins from LAB has been largely driven by commercial imperatives (Heng et al., 2007) in the food industry, where bacteriocin producing $\mathrm{LAB}$ and bacteriocins such as nisin and pediocin have limited application as additives to prevent the growth of food-poisoning and food-spoilage bacteria (Zacharof and Lovitt, 2012). This narrow spectrum of application is based on the general knowledge that bacteriocins are short-chain peptides with antimicrobial activity against closely related bacteria. More recently, however, several bacteriocins have been shown to exhibit broad spectrum activity against a wide range of bacteria (Kwon et al., 2002; Mlalazi et al., 2011; Muller et al., 2009; Todorov and Dicks, 2005). Given this potential, this study's primary objective was to characterize bacteriocins from LAB capable of inhibiting multidrug-resistant, extended spectrum beta-lactamase Gramnegative bacteria. The prevalence of multidrug-resistance cannot be over emphasized. In 2014, the World Health Organization (WHO) noted that a postantibiotic era in which common infections and minor injuries can kill is a real possibility for the 21 st century, and that the scarcity of new classes of antimicrobial drugs for Gram-negative bacteria adds additional urgency.

To the best of our knowledge, the current study is the first to show a Lactobacillus parafarraginis species inhibiting the growth of multidrug-resistant and extended spectrum $\beta$-lactamase Gram-negative bacteria from clinical specimens, and the first reported finding of this isolate in yogurt. 


\section{MATERIAL AND METHODS}

\section{Isolation of LAB from yogurt}

LAB were isolated from 15 randomly selected commercial yogurts. Eleven (11) grams of each yogurt were aseptically transferred into a stomacher bag and combined with $99 \mathrm{~mL}$ of $0.01 \%$ of proteose peptone (DB Difco). Each combination was homogenized in a stomacher laboratory blender (80, Seward, UK) for $60 \mathrm{sec}$. Volumes of $0.1 \mathrm{~mL}$ from 10 fold serial dilutions, of the homogenized specimen, were plated on de Man Rogosa Sharpe (MRS) agar (DB Difco) and incubated anaerobically at $37^{\circ} \mathrm{C}$ for $72 \mathrm{~h}$ (Mlalazi et al., 2011) Countable plates were enumerated and colonies randomly selected, propagated, and used for antimicrobial screening using spot-test assay. Type cultures (indicators organisms) used for spot testing included Staphylococcus aureus (ATCC 6538), Listeria monocytogenes (ATCC 7644) and Escherichia coli O157:H7 (ATCC 35150). One isolate, A1 (KU495926), exhibiting broad spectrum antimicrobial activity against these cultures, was selected for further studies.

\section{Detection of inhibitory activity of strain A1 (KU495926)}

The antimicrobial activity of strain A1 (KU495926) was assessed by utilizing spot tests, well-diffusion assays, live dead assays (flow cytometry and fluorescence microscopy) in parallel with aerobic plate count. The spot testing method (Mohankumar et al. 2011) was modified and utilized in preliminary screening against the indicators organisms Staphylococcus aureus (ATCC 6538), Listeria monocytogenes (ATCC 7644) and Escherichia coli O157:H7 (ATCC 35150) and subsequent testing with fourteen (14) multidrug resistant and extended spectrum $\beta$-lactamase Gram-negative organisms from six genera Escherichia coli (5), Pseudomonas aeruginosa (2), Acinetobacter baumannii/haemolyticus (3), Enterobacter aerogenes (1), Proteus mirabilis (2) and Klebsiella pneumoniae (1), isolated from clinical specimens at a loca Washington D.C hospital (USA) (Table 1). Other indicator organisms tested include Pseudomonas aeruginosa (culture collection), Serratia marcescens (culture collection), Shigella sonnei ATCC 11060, Yersinia enterocolitica (ATCC 23715), Streptococcus pyogenes (ATCC 19615), Bacillus cereus (culture collection), Enterococcus faecalis (ATCC 29212) and Staphylococcus aureus (culture collection). Pure colonies of strain A1 ((KU495926)) were inoculated in MRS broth and incubated anaerobically at $37^{\circ} \mathrm{C}$ for $72 \mathrm{~h}$. The broth was then vortexed and $1.5 \mathrm{~mL}$ pipetted into a sterile microfuge tube. The sample was then centrifuged at room temperature for $10 \mathrm{~min}$ at 14,000 rpm (Eppendorf centrifuge $5415 \mathrm{C}$ ). The supernatant was decanted in another tube and $20 \mu \mathrm{L}$ aliquoted and used to re-suspend the bacterial residue. A sterile Pasteur pipette was used to make approximated $1 \mathrm{~mm}$ wells on the surface of MRS agar plates. A volume of $1 \mu \mathrm{L}$ of the re-suspended residue was pipetted in each indentation created. The plates were then incubated at $37^{\circ} \mathrm{C}$ anaerobically for approximately $24 \mathrm{~h}$. Samples of exponential growth phase cultures (grown overnight on TSA, BHI or Heart Infusion agar) of the indicator organisms were prepared to concentrations equivalent to that of a $0.5 \mathrm{McF}$ arland by inoculating isolated colonies in sterile saline. McFarland standard was prepared based on protocol found elsewhere (McFarland, 1907) . The optical density was evaluated at $\mathrm{OD}_{625} \mathrm{~nm}$ (Bausch \& Lomb Spectronic 601) with a reading of $0.100 \pm 0.001$. A $1 \mathrm{~mL}$ sample of (McFarland equivalent) indicator organism was mixed with $8 \mathrm{~mL}$ of liquefied $1 \%$ TSA, BHI agar or Heart infusion agar. The individual preparations were then poured over the colonies of strain A1 ((KU495926)) organism grown on the MRS agar plates. The TSA agar/BHI/ Heart infusion agar was then allowed to solidify on top of the MRS agar and the plates incubated aerobically at $37^{\circ} \mathrm{C}$ for $24-48 \mathrm{~h}$ Following the incubation period, the zones of inhibition observed were measured $(\mathrm{mm})$. The experiment was repeated a minimum of four times for each indicator organism.

A modified version of the well diffusion assay used by Kazemipoor et al 2012 (Kazemipoor et al., 2012) was utilized. Briefly, the indicator organisms were grown on tryptic soy agar plates at $37^{\circ} \mathrm{C}$ for $18-24 \mathrm{~h}$ (instead of growing in $\mathrm{BHI}$ then suspended in sterile saline to make $0.5 \mathrm{McFarland}$ standard equivalents. A lawn of the indicator organism was prepared by applying the McFarland standard equivalent to the surface of TSA plates by means of a sterile cotton swab
(Puritan $\left.{ }^{\circledR}\right)$. A sterile well borer of diameter $5 \mathrm{~mm}$ was then used to cut uniform wells in the inoculated TSA plates. Each well was then filled with $80 \mu \mathrm{L}$ of the cell free supernatant (CFS) obtained from the LAB isolate. The CFS was prepared by filtering $\sim 72 \mathrm{~h}$ old MRS broth cultures of A1 ((KU495926)) with $0.22 \mu \mathrm{m}$ filters. The CSF was concentrated by utilizing a speed vacuum centrifuge (Integrated Speed $\operatorname{Vac}{ }^{\circledR}$ System ISS110- Savant) (Mlalazi et al. 2011) to reduce samples to at least a third of their original volume (3× concentrated). The prepared plates were then incubated at $37^{\circ} \mathrm{C}$ for $16-24 \mathrm{~h}$ and the diameter of the zone of inhibition ascertained with a millimeter rule. At least four readings were derived for each indicator organism.

Time Lapse Studies of the Effect of A1 (KU495926) CFS/Bacteriocin on the Growth of MDR/ ESBL Gram-negative Bacteria using Fluorescence Microscopy and Aerobic Plate Count.

Pseudomonas aeruginosa (HUH06), a multidrug-resistant indicator organism, was utilized in time lapse studies to verify the effect of the CFS of the Lactobacillus isolate. Briefly, $500 \mu \mathrm{L}$ of $0.5 \mathrm{McFarland}$ standard equivalent of exponential growth phase P. aeruginosa (HUH06), O.D ${ }_{625 \mathrm{~mm}}=0.087$ were combined with $500 \mu \mathrm{L}$ of $0.2 \mathrm{~g} / \mathrm{mL}$ distilled $\mathrm{H}_{2} \mathrm{O}$-lyophilized CFS. A volume of $3 \mu \mathrm{L}$ of live-dead stain (Invitrogen L7012 Live-Dead Backlight ${ }^{\mathrm{TM}}$ Bacterial Viability Kit- (SYTO 9 and propidium iodide combined 1:1)) was then added to the $1000 \mu \mathrm{L}$ preparation. The preparation was briefly vortexed and incubated at $37^{\circ} \mathrm{C}$. Samplings were done at intervals of $0.5,2,4,6,8,24,48,72,96,120$ and 144h. A total of five experiments were done. Lyophilized MRS sample of the same volume and concentration $(0.2 \mathrm{~g} / \mathrm{mL})$ as the CFS was utilized in control experiments. At each sampling point, the tubes were briefly vortexed and $5 \mu \mathrm{L}$ placed on a sterile microscope slide and photographed under the EVOS Digital Inverted Microscope (Advance Microscopy Group). Additionally, the microbial population in each microfuge tube was monitored in parallel with EVOS viewing by using micro-samplings to do standard plate counts. One (1) $\mu \mathrm{L}$ of sample was removed from the microfuge tube and placed in $9 \mathrm{~mL}$ of sterile saline. After vortexing the tube, subsequent 1:10 dilutions were done and $0.1 \mathrm{~mL}$ plated on trypticase soy agar plates. Plates were incubated aerobically at $37^{\circ} \mathrm{C}$ overnight and $\mathrm{cfu} / \mathrm{mL}$ enumerated. Similar experiments were done with A. baumannil (HUH11).

Time Lapse and Flow Cytometry Assessment of A1 ((KU495926)) CFS/Bacteriocin efficacy on Growth of MDR/ ESBL Gram-negative Bacteria

Flow cytometric analyses (BD Accuri ${ }^{\mathrm{TM}} \mathrm{C} 6$ Plus Flow Cytometer) were done to further verify the inhibitory action of strain A1 ((KU495926)) CFS against Escherichia coli (HUH12), A. baumannii (HUH08) and P. aeruginosa (HUH06) A uniform suspension of exponential growth phase culture of each bacterium was prepared by inoculating pure colonies in sterile saline solution each with $\mathrm{OD}_{625 \mathrm{~nm}}$ $=\sim 0.3$. A volume of $500 \mu \mathrm{L}$ of each bacterial suspension was combined with 500 $\mu \mathrm{L}$ of the Lactobacillus CFS ( $3 \times$ speed vacuum concentrated) in triplicates. Control experiments were set up for each organism with $500 \mu \mathrm{L}$ MRS broth (3× speed vacuum concentrated) instead of strain A1 ((KU495926)) CFS. Three microliters of L7012 Live-Dead Backlight ${ }^{\mathrm{TM}}$ fluorescence dyes (SYTO 9 and propidium iodide combined 1:1) were also added to all microfuge tubes. The tubes were then incubated at $37^{\circ} \mathrm{C}$ and analyzed using BD Accuri' ${ }^{\mathrm{TM}} \mathrm{C} 6$ Plus flow cytometer at times 5 and $96 \mathrm{~h}$. The green fluorescence of SYTO 9 (indicated live bacteria) and red fluorescence of propidium iodide (indicated dead/damaged bacteria) were evaluated by the standard optical filters 533/30 nm (FL1) and 670 LP nm FL3 respectively (Berney et al., 2007; Elshikh et al., 2016; Joshi et al., 2006). The equipment was set at a flow rate of 10,000 events per second. The live-dead data captured by the optical filters were analyzed both graphically and by doing Repeated Measures ANOVA (RMA) using SPSS statistical software, version 23 (Singh et al., 2013) to determine any significant difference between mean number of organisms alive in strain A1 ((KU495926)) CFS compared to the MRS broth. 
Table 1 Antibiogram data of Multidrug-Resistant and Extended Spectrum Beta-lactamase Gram-negative bacteria isolated from clinical specimens at a local Washington D.C. Hospital

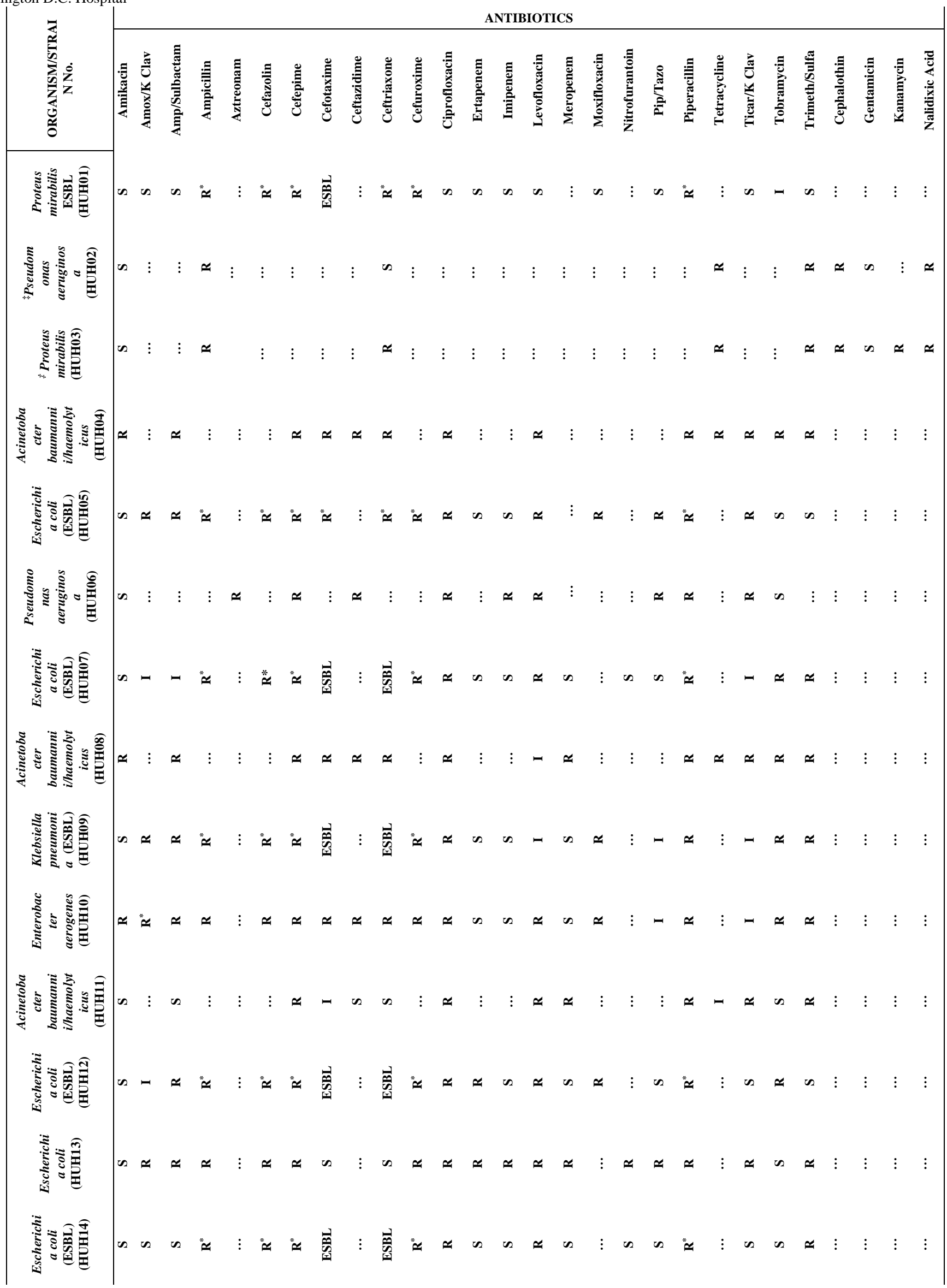

$\mathrm{S}=$ Susceptible; $\mathrm{I}=$ Intermediate $; \mathrm{R}=$ Resistant; $\mathrm{R}^{*}=$ Predicted resistance; ESBL = Extended spectrum beta-lactamases; $\ldots=$ Not Tested; Amox/K Clav = Amoxicillin clavulanic acid; Pip/Tazo = Piperacillin/tazobactam; Ticar/ K Clav $=$ Ticarcillin Clavulanic acid; Trimeth/Sulfa $=$ Trimethoprim Sulfamethoxazole. All antibiogram data were generated by the hospital's laboratory (Microscan and Etest) excepting those marked $\ddagger$ (determined by Kirby- Bauer Disc diffusion). 
Determining minimum inhibitory concentration (MIC) and minimum bactericidal concentration (MBC) of CFS

A 0.5 McFarland standard equivalent was prepared in sterile saline for each of the 14 isolated clinical pathogens using exponential growth phase cultures (grown overnight on TSA; 16-18h old). One hundred and sixty (160) $\mu \mathrm{L}$ of a $20 \mathrm{mg} / \mathrm{mL}$ distilled $\mathrm{H}_{2} \mathrm{O}$-lyophilized sample of strain A1 (KU495926) CFS was added to each of the first test wells on 96 well plates (Corning Incorporated USA). Eighty (80) $\mu \mathrm{L}$ of heart infusion broth (Difco; USA) was then added to all other wells. Serial dilution of the A1 CFS was done by transferring $80 \mu \mathrm{L}$ of solution from the first well to subsequent wells in each vertical row, ensuring proper mixing of the contents in each well before transfer. The final $80 \mu \mathrm{L}$ were discarded. Ten (10) $\mu \mathrm{L}$ of the $0.5 \mathrm{McF}$ arland standard equivalent prepared for each pathogen was added to each well in the appropriately labeled vertical row. Ten (10) $\mu \mathrm{L}$ of $6.75 \mathrm{mg} / \mathrm{mL}$ resazurin (Sigma company; USA) solution were added to all wells. The 96 well plates were incubated overnight and then evaluated macroscopically to determine the MIC (Allen et al., 2012). To determine $\mathrm{MBC}$ an inoculum from each well was applied to the surface of TSA, incubated overnight then observed for growth. Similar experiments using lyophilized MRS broth were set up as control.

\section{Effect of temperature on the activity of CFS}

Aliquots of $0.2 \mathrm{~g} / \mathrm{mL}$ lyophilized cell free supernatant dissolved in sterile distilled water were subjected to heat treatments of 40,80 and $100^{\circ} \mathrm{C}$ for $30 \mathrm{~min}$ and autoclaved at $121^{\circ} \mathrm{C}$ for $20 \mathrm{~min}$. The samples were cooled and tested for antimicrobial activity via well- diffusion assay (van Reenen et al., 1998).

\section{Effect of pH on the activity of CFS}

The initial $\mathrm{pH}$ (4.46) of $3 \mathrm{x}$ speed vacuum concentrated CFS of strain A1 (KU495926) was determined by using a pH meter (Thermo-electron cooperation) and aliquots used for controlled experiments. Additional aliquots were adjusted to $\mathrm{pH} 2,3,4,5,6,7,8,9$ and 10 by using $1 \mathrm{M}$ sodium hydroxide and hydrochloric acid (Joshi et al., 2006). The prepared samples were allowed to stand at room temperature for $1 \mathrm{~h}$ and then assayed for activity against four indicator organisms (E. coli (HUH12), A. baumannii (HUH04), E. faecalis (ATCC 29212) and B. cereus) via well-diffusion as described earlier. The diameters of the zones of inhibition $(\mathrm{mm})$ were measured following overnight incubation at $37^{\circ} \mathrm{C}$. An average of three measurements were taken for each $\mathrm{pH}$.

\section{Tricine SDS-PAGE to detect bacteriocin released by $L$. parafarraginis KU494926}

Cell free supernatant was prepared as previously mentioned from various aged culture of the Lactobacillus spp. (5 months, 3 months, 13 days, 5 days and $\sim 72$ h). These CFS samples were $3 \times$ speed vacuum concentrated (Integrated Speed Vac ${ }^{\circledR}$ System ISS110- Savant) and used for SDS-PAGE. Both precast gels (Biorad ${ }^{\circledR}$ Mini-Prortean ${ }^{\mathrm{TM}}$ TGX 4-20\% gel) and self-made gels (Schagger, 2006) were utilized in this study. Molecular weight marker with range 3.5-245 kDa (Flash Protein Ladder, Gel-Company- San Francisco, U.S.A) and 10-250 kDa (BioRad unstained Precision Plus protein ladder) were utilized. Gels were stained by using Coomassie Blue R250 and/or Imidazole-SDS-Zinc (Gillespie and Elliott, 2005).

SDS-PAGE was also used to detect bacteriocin production along the growth curve of L. parafarraginis (KU495926). Colonies L. parafarraginis grown under anaerobic conditions at $37^{\circ} \mathrm{C}$ for $\sim 72 \mathrm{~h}$ were inoculated in $10 \mathrm{~mL}$ of MRS broth The broth was incubated at $37^{\circ} \mathrm{C}$ for $16 \mathrm{~h}$ under the previously mentioned conditions, vortexed and $1 \mathrm{~mL}$ added to each of three Erlenmeyer flasks containing $200 \mathrm{~mL}$ of MRS broth. The flasks were incubated at $37^{\circ} \mathrm{C}$ under anaerobic conditions with constant agitation. Samples of CFS supernatant were prepared from the flasks at times :0, 3, 6, 12, 15, 18, 21, 24, 36, 48, 60,72 and 96 $\mathrm{h}$ by filter sterilizing aliquots of $5 \mathrm{~mL}$ using $0.22 \mu \mathrm{m}$ syringe filters. Samples were stored at $-20^{\circ} \mathrm{C}$ until further use. The optical densities of the cultures were also assessed at each time by aspirating $1 \mathrm{~mL}$ samples $\left(\mathrm{OD}_{625 \mathrm{~nm}}\right.$ against MRS blank) and the average density at each time used to generate a growth curve. A volume $0.5 \mathrm{~mL}$ of CFS collected for each time was centrifuged (Integrated Speed Vac $\mathbb{R}$ System ISS110- Savant) and pellet reconstituted with $50 \mu \mathrm{L}$ of sterile deionized water. The reconstituted samples were utilized for SDS-PAGE. A volume of 0.5 $\mathrm{mL}$ MRS broth was treated in the same manner as the CFS and electrophoresed as a negative control. Activity unit with time was also assessed by utilizing the indicator organism E. coli (HUH14). A volume of $1.5 \mathrm{~mL}$ of CFS collected a each time was concentrated thrice by centrifuging and $80 \mu \mathrm{L}$ utilized per well (created with a $5 \mathrm{~mm}$ well borer). The assays were done in triplicate and the zones of inhibition measured $(\mathrm{mm})$. The average zones of inhibition were used to determine activity unit per/mL (AU/mL) using the formula (Iyapparaj $\boldsymbol{e t}$ al. 2013): $\mathrm{AU} / \mathrm{mL}=($ Diameter of the zone of clearance $(\mathrm{mm}) \times 1000) \div$ Volume placed in the well $(\mu \mathrm{L})$. A graph of AU/mL of CFS and growth of $L$. parafarraginis (KU495926) was generated (Goh and Philip, 2015). An average of four $\mathrm{pH}$ readings was also taken for CFS collected at each time (Thermo electron co-operation Orion2 Star $\mathrm{pH}$ Benchtop $\mathrm{pH}$ meter). Average aerobic plate count of E. coli (HUH14) was also assessed with CFS collected for each time along the growth curve. For the aerobic plate count a volume of $500 \mu \mathrm{L}$ of each timed CFS was combined with $500 \mu \mathrm{L}$ of $E$. coli $(\mathrm{HUH} 14) \mathrm{OD}_{625 \mathrm{~nm}}=0.313$ (Ultrospec 2100 pro UV/visible spectrophotometer) in sterile microfuge tubes and incubated with constant agitation at $37^{\circ} \mathrm{C}$ overnight $(\sim 16 \mathrm{~h})$. The content of each microfuge tube was then added to $10 \mathrm{~mL}$ of sterile saline solution vortexed and serially diluted up to a dilution factor of $10^{-5}$. Triplicate plating was done on Brain Heart Infusion agar plates for each dilution.

\section{Partial purification of bacteriocin}

Seventy-two hours CFS of L. parafarraginis KU494926 was prepared as previously mentioned. The samples were $6 \times$ speed concentrated (Integrated Speed Vac ${ }^{\circledR}$ System ISS110- Savant) and loaded in a sterile tube onto the BioCAD 700E perfusion liquid chromatography workstation. The mobile phase and eluent used were $0.45 \mu \mathrm{m}$ filter sterilized; $10 \mathrm{mM}$ sodium phosphate buffer (pH 4.99) and $10 \mathrm{mM}$ sodium phosphate containing $1 \mathrm{M} \mathrm{NaCl} \mathrm{pH} 4.58$ respectively (Håvarstein, Holo, \& Nes, 1994). A HiTrap ${ }^{\mathrm{TM}}$ SP Sepharose FF, 1 $\mathrm{mL}$ cationic exchange column was used at a flow rate of $1 \mathrm{~mL} / \mathrm{min}$. A dual UV detector set at 254 and $280 \mathrm{~nm}$ was used for protein detection. Fractions were collected by peak cutting into sterile $15 \mathrm{~mL}$ tubes using Avantec SF-2120 Super Fraction Collector. Fractions unique to particular peaks were pooled and concentrated by speed vacuum and antimicrobial activity evaluated via welldiffusion assay. The combined fraction showing activity was further evaluated. Following fractionation and combination, desalting and concentrating of $500 \mu \mathrm{L}$ combined fractions was done with Microcon $®$ centrifugal filtering device $3 \mathrm{kDa}$ cut-off-point, and further concentration was done for $1 \mathrm{~h}$ by speed vacuuming. A volume of $5 \mu \mathrm{L}, 0.2 \mu \mathrm{m}$ filter sterilized $\mathrm{pH} 4.43$ deionized water was added to the tube to enhance optimal $\mathrm{pH}$ for activity. MRS broth (control) was treated in a similar manner as the strain A1 ((KU495926)) CFS. Eighty microliters of the prepared desalted fractions, as well as the sterilized deionized water $(\mathrm{pH} \mathrm{4.43)}$ were assayed for activity via well-diffusion assay. SDS-PAGE was also done on individual fractions as well as the combined fractions.

\section{The effect of proteolytic enzymes on partially purified bacteriocin}

The effect of proteolytic enzymes on partially purified bacteriocin was determined as mentioned elsewhere (Sharma and Neha., 2008). Active FPLC fractions containing bacteriocin was combined in a 1:1 ratio with individual enzymatic solution, incubated at $37^{\circ} \mathrm{C}$ for $1 \mathrm{~h}$, then heated for $3 \mathrm{~min}$ at $100^{\circ} \mathrm{C}$ for enzyme inactivation prior to diffusion assay (van Reenen et al., 1998). The enzymes utilized included pepsin, papain, trypsin, $\alpha$ - chymotrypsin and proteinase K (Fisher Science Education and Sigma; USA). The CFS was also treated with previously mentioned enzymes (excepting papain) as well as $\alpha$ amylase, peptidase, lipase A and catalase.

\section{PCR Detection of Bacteriocin Structural Genes}

Twenty sets of bacteriocin primers (Table 2) were used for the detection of bacteriocin structural genes as mentioned elsewhere (Macwana and Muriana 2012). The bacterial DNA was extracted from $1 \mathrm{~mL}$ of exponential growth phase population in MRS broth. The sample was centrifuged at 12,000 rpm for $5 \mathrm{~min}$, the supernatant decanted, and the pellet resuspended in $750 \mu \mathrm{L}$ of $50 \mathrm{mM}$ EDTA (Fisher Scientific; USA), followed by the addition of $100 \mu \mathrm{L}$ of a solution of 50 $\mathrm{mg} / \mathrm{mL}$ lysozyme (Sigma; USA) (Abdulla, 2014). The protocol was then observed as outlined by QIAamp (DNA mini kit). Post extraction, the purity and concentration of the DNA was determined (Thermo-Scientific NanoDrop 2000c), and PCR performed (Bio-Rad MJ Mini Personal Thermal Cycler). The annealing temperatures for the various primers were determined in-silico (Themo Scientific calculator, https://www.thermofisher.com/us/en/home/brands/thermoscientific/molecular-biology/molecular-biology-learning-center/molecularbiology-resource-library/thermo-scientific-web-tools/tm-calculator.html). PCR reaction volume of $25 \mu \mathrm{L}$ consisted $1 \mu \mathrm{L}$ of DNA template $(22.3 \mathrm{ng} / \mu \mathrm{L})$, $0.5 \mu \mathrm{L}$ of forward and reverse primers $(25$ picomol $/ \mu \mathrm{L}), 12.5 \mu \mathrm{L}$ of Lucigen ${ }^{\circledR}$ Econo Taq ${ }^{\circledR}$ Plus $2 \mathrm{X}$ Master Mix and $10.5 \mu \mathrm{L}$ of water (molecular grade). The thermal cycler was programmed with a pre-incubation period of $2 \mathrm{~min}$ at $94^{\circ} \mathrm{C}$ and for 35 cycles each consisting denaturation for $30 \mathrm{~s}$ at $94^{\circ} \mathrm{C}$, the appropriate annealing temperature for $30 \mathrm{~s}$, elongation for $1 \mathrm{~min}$ at $72^{\circ} \mathrm{C}$. A final elongation of $10 \mathrm{~min}$ at $72^{\circ} \mathrm{C}$ proceeded the 35 cycles. The amplicons were electrophoresed using $0.8 \%$ agarose gel containing $5 \mu \mathrm{L}$ of $10 \mathrm{mg} / \mathrm{mL}$ ethidium bromide per 100 $\mathrm{mL}$ of gel. The electrophoresed gels were viewed either with Kodak Gel Logic 100 Imaging System or Li-cor Odyssey Fc Imaging system.

Amplicons for $s a k T-\beta$ gene were cleaned-up using QIAquick PCR purification Kit, while those for $s a k T-\alpha, a c d T$ and $p \ln c 8 A$ were extracted from the agarose gel (Monarch DNA gel extraction kit) and the amplification repeated. Sanger sequencing was performed by Genewiz ${ }^{\circledR}$ Inc. (South Plainfield, NJ), and sequences evaluated using Applied Biosystems (ABI) Sequence Scanner software 2 , and the homologies evaluated using NCBI BLAST (https://blast.ncbi.nlm.nih.gov/Blast.cgi). Pairwise comparisons were done with 
the sequences for sakT- $\beta$ and sakT- $\alpha$ by with Lactobacillus sakei IP-TX (GenBank accession, AY206863.1). Similarly, comparisons were done between the acdT gene sequence and acdT gene from Lactobacillus acidophilus (GenBank accession, D43626.1), and between the plnc8A gene sequence and plnc8A gene of Lactobacillus plantarum (GenBank accession, AB552848.1). BLASTX was also used to do conceptual translation of the sequences and queries against protein databases. The bacteriocin genome mining tool BAGEL3 (http://bagel.molgenrug.nl/index.php/bacteriocin-database/) (van Heel et al. 2013; Walsh et al., 2015) was used to do comparative analyses with the sequenced bacteriocin structural genes and those in : Lactobacillus buchneri CD034, Lactobacillus acidophilus 30SC, Lactobacillus acidophilus La 14 Lactobacillus acidophilus NCFM and Lactobacillus plantarum subsp. plantarum $\mathrm{P} 8$.

Table 2 Primers used in this study

\begin{tabular}{|c|c|c|c|c|}
\hline Baccteriocin Gene & $\begin{array}{c}\text { Forward Primer } \\
\left(5^{\prime}-3^{\prime}\right)\end{array}$ & $\frac{\text { Reverse Primer }}{\left(5^{\prime}-3^{\prime}\right)}$ & Name of Bacteriocin* & Primer Reference \\
\hline papA & ttacttgtggcaaacattcctg & tgattaccttgatgtccaccag & Pediocin & (Macwana and Muriana, 2012) \\
\hline breB & atggagaaattcgcagtgttatc & tgttatttaggcagctaattgca & breB brevicin $925 \mathrm{~A}$ & (Macwana and Muriana, 2012) \\
\hline breC & atgtataaagaattaacagttgatgaatt & gtgcatgecgtgtaagttgt & breC brevicin $925 \mathrm{~A}$ & (Macwana and Muriana, 2012) \\
\hline $\operatorname{plnc} 8 A$ & ctagaaaagatctctggcggtg & catatgggtgctttaaattcca & $\begin{array}{l}\text { Plantaricin.NC8 alpha } \\
\text { peptide }\end{array}$ & (Macwana and Muriana, 2012) \\
\hline$p \operatorname{lnc} 8 B$ & ggcaagagtagcttgtctcaaa & caatcgttttgcgatgcttat & $\begin{array}{l}\text { Plantaricin NC8 beta } \\
\text { peptide }\end{array}$ & (Macwana and Muriana, 2012) \\
\hline Enterocin AS48 & gaggagtatcatggttaa aga & atattg ttaaattac caa & Enterocin AS48 & (Mirhosseini et al., 2008) \\
\hline curvacin A & atgaataatgtaaaagaattaagtatgaca & tccagctaaaccactagccc & Curvacin A & (Macwana and Muriana, 2012) \\
\hline mesB & aaacaaatttcaaaatcctttcaga & atttgtggttcttgatctttgc & Mesentericin B105 & (Macwana and Muriana, 2012) \\
\hline$a c d T$ & aaagaattagcattaatttctgggg & cgtcagtataacgaaggctttccc & Acidocin T8912 & (Macwana and Muriana, 2012) \\
\hline helveticin & atgattggaaaagaaactcaaatac & aataaaggcaatcaccagttactt & Helveticin & (Macwana and Muriana, 2012) \\
\hline$\alpha$-peptide & aacaattggtggtggcatgt & tatccaagacgtccetttttgt & Lactocin- $\alpha$ & (Macwana and Muriana, 2012) \\
\hline$\beta$-peptide & gaaaaatttgccaatatctcgaa & accattaattggtgaatggtga & Lactocin- $\beta$ & (Macwana and Muriana, 2012) \\
\hline $\operatorname{sakT-\alpha }$ & tcggtggctatactgctaaaca & tgtcctaaaaatccaccaatgc & SakacinT- $\alpha$ & (Macwana and Muriana, 2012) \\
\hline$s a k T-\beta$ & aagaaatgatagaaatttttggagg & tgtgaaatccaatcttgtcctg & SakacinT- $\beta$ & (Macwana and Muriana, 2012) \\
\hline laf & agtcgttgttggtggaagaaat & tcttatettgccaaaaccacct & Lactacin F & (Macwana and Muriana, 2012) \\
\hline NisZ & atgagtacaaaagattttaacttgg & ttatttgcttacgtgaatactaca & Nisin Z & (Macwana and Muriana, 2012) \\
\hline Bacl47 & accaatgtttggtttgaactgta & aaaattacttgtttcaacacttatcct & Nisin U & (Macwana and Muriana, 2012) \\
\hline gaa A & cggacgtaatttaggtttgaaca & aagcccatgcaggtaatgtc & Gassericin A & (Macwana and Muriana, 2012) \\
\hline B-Talla & gtaacggagttcattgcacaaa & taccagaaaccatttccaccat & $\begin{array}{c}\text { Leucocin-B (Leucocin } \\
\text { B-Ta11a) }\end{array}$ & (Macwana and Muriana, 2012) \\
\hline lclA & aaaccaagtctctcgtattggc & ggcacgttgtgtatcettacet & Lactococcin A & (Macwana and Muriana, 2012) \\
\hline
\end{tabular}

Phenotypic characterization of strain A1 ((KU495926))

The colony morphology of isolate A1, propagated on MRS agar plates was determined via stereoscopy (Fisher Stereomaster). The organism was further characterized by doing various biochemical and physiological tests. These included Gram-stain, endospore stain, catalase, oxidase, gelatin liquefaction and motility tests (BD BBL ${ }^{\mathrm{TM}}$ Motility Test Medium). DNase (BD Difco), urea hydrolysis, tryptophan hydrolysis, methyl red, Voges-Proskeur, nitrate, citrate, growth in Kliger iron agar (BBL), sulphur-indole-motility (SIM) agar (BBL), lysine-iron-agar (LIA, (BBL)), nutrient broth (OXOID) and fermentation of lactose, glucose, sucrose, bile esculin and mannitol were also evaluated under both aerobic and anaerobic conditions via conventional methods. Its ability to ferment forty-nine (49) carbohydrates was also evaluated via API-50CH (BioMèrieux ${ }^{\circledR}$ SA, France), (Nigatu, 2000) and the data garnered fed into a database provided by the manufacturer (http://apiweb.biomerieux.com) to ascertain the identity of the organism (Mlalazi et al., 2011). Carbon-dioxide production from dextrose metabolism in MRS was verified by bubbling the gas released into filtered $0.1 \mathrm{M}$ barium hydroxide solution (Fisher scientific; USA).

The effect of $\mathrm{pH}$, temperature, sodium chloride $(\mathrm{NaCl})$ concentration as well as presence and absence of oxygen on growth of the organism were evaluated Growth in nutrient broth at $\mathrm{pH} 3,7$ and 9 was monitored by measuring optical density $\left(\mathrm{OD}_{625 \mathrm{~nm}}\right.$ against nutrient broth blank) over a $75 \mathrm{~h}$ period. An overnigh MRS broth culture of $\mathrm{A} 1\left(\mathrm{OD}_{625 \mathrm{~nm}}, 0.105\right.$, grown at $37^{\circ} \mathrm{C}$ anaerobically) was homogenized with a vortex and $1.5 \mathrm{~mL}$ of the specimen dispensed in $13.5 \mathrm{~mL}$ of nutrient broth at the different $\mathrm{pH}$. Samples were incubated at $37^{\circ} \mathrm{C}$ anaerobically and vortexing followed by $1 \mathrm{~mL}$ samplings done at times: $0,5,10,15,30,40,55$, 60 and $75 \mathrm{~h}$. The optical densities of the samples were monitored with Spectronic ${ }^{\circledR}$ Genesys ${ }^{\mathrm{TM}}$ spectrophotometer. The effect of $\mathrm{NaCl}$ concentration was evaluated by using a $16 \mathrm{~h}$ MRS broth culture of $\mathrm{A} 1\left(\mathrm{OD}_{625 \mathrm{~nm}}, 1.724\right) ; 5 \mathrm{~mL}$ of this broth culture were pipetted into $20 \mathrm{~mL}$ nutrient broth of each salt concentration $(0.5 \%, 6.5 \%, 10 \%$, and $15 \%)$. The optical densities of the samples were monitored with Spectronic ${ }^{\circledR}$ Genesys ${ }^{\mathrm{TM}}$ spectrophotometer similar to the experiment for effect of $\mathrm{pH}$. At the end of the $75 \mathrm{~h}$ assessment period a $1 \mathrm{~mL}$ sample form each salt concentration was pipetted in $4 \mathrm{~mL}$ of MRS broth, incubated anaerobically at $37^{\circ} \mathrm{C}$ for $48 \mathrm{~h}$ and then streaked on MRS agar to assess viability of the cultures. Growth on MRS agar slants at $0^{\circ} \mathrm{C}, 4^{\circ} \mathrm{C}, 25^{\circ} \mathrm{C}, 37^{\circ} \mathrm{C}$ and $45^{\circ} \mathrm{C}$ was assessed both aerobically and anaerobically. Samples were incubated at each temperature for 3 days.

The generation time of strain A1 in MRS broth was estimated both aerobically and anaerobically. Results were derived from two experiments which were conducted in duplicate under each condition. Each experiment was initiated by pipetting $1 \mathrm{~mL}$ of a homogenized overnight anaerobic broth culture into two sets of $20 \mathrm{~mL}$ MRS broth. All tubes were vortexed and one set of two was incubated under aerobic conditions and the other under anaerobic conditions at $37^{\circ} \mathrm{C}$ with constant agitation. The optical densities of $1 \mathrm{~mL}$ samplings (Spectronic $\mathbb{R}$ Genesys $^{\mathrm{TM}}$ spectrophotometer) were obtained over an $80 \mathrm{~h}$ period at times: 0,20 ,
40, 60 and $80 \mathrm{~h}$. The standard plate count of each sample was determined at each time interval by pipetting $1 \mathrm{~mL}$ into $9 \mathrm{~mL}$ of saline, with subsequent serial 10 fold dilutions of up to $10^{-7}$ and $10^{-8}$, with duplicate plating of $0.1 \mathrm{~mL}$ on MRS agar plates. These plates were incubated anaerobically for $72 \mathrm{~h}$ at $37^{\circ} \mathrm{C}$ and then enumerated. The bacterial load was reported as colony forming units per $\mathrm{mL}$ (CFU/mL) (Awua et al., 2012).

\section{Microbial fatty acid profile}

The microbial fatty acid profile of the organism was determined by gas chromatography/mass spectrometry (GC/MS) analysis (Agilent Technologies $6890 \mathrm{~N}$ Network GC system). The samples for fatty acid methyl ester (FAME) were prepared by harvesting colonies from pure culture of the organism grown on MRS agar. Fifty (50) mg of bacteria were aseptically added to a glass tube. Fattyacids were saponified by the addition of a solution containing $0.45 \mathrm{~g}$ sodium hydroxide, $1.5 \mathrm{~mL}$ methanol and $1.5 \mathrm{~mL}$ distilled water. This preparation was vortexed briefly and heated for $5 \mathrm{~min}$ at $100^{\circ} \mathrm{C}$ in a water bath. Re-vortexing and re-heating at the same temperature then followed for $10 \mathrm{~s}$ and $30 \mathrm{~min}$ respectively. The tube was then allowed to cool to $25^{\circ} \mathrm{C}$ and the saponified fatty acids methylated by adding $2 \mathrm{~mL}$ of a reagent containing 3.25 of $6 \mathrm{M}$ hydrochloric acid and $2.75 \mathrm{~mL}$ methanol. The latter preparation was briefly vortex and reheated at $81^{\circ} \mathrm{C}$ for $11 \mathrm{~min}$. Extraction of the fatty-acid methyl ester (FAME) then followed with the addition of $1.25 \mathrm{~mL}$ of a solution containing 1:1 hexane; methyl tertbutyl ether (MTBE). Subsequent mixing of the tube for 10 minutes was then ensued and the aqueous (lower) phase removed. The remaining organic phase was then washed by the addition of a solution containing $0.11 \mathrm{~g}$ of $\mathrm{NaOH}$ in $9 \mathrm{~mL}$ of distilled water. The organic phase was then removed to a new tube for analysis by GC/MS (Allen et al., 2012; McNabb et al., 1997).

\section{Positive staining for Transmission Electron Microscopy (TEM)}

A $1 \mathrm{~mL}$ sample of 12 days old MRS broth culture of the organism was placed in a sterile Eppendorf tube and centrifuged at 14,000 rpm for $10 \mathrm{~min}$ followed by removal of the supernatant. The bacterial residue was then washed six times with phosphate buffered saline. Three (3) $\mu \mathrm{L}$ of the sample were then placed on the dull side of a copper grid and allowed to stand for 5 min. Five (5) $\mu \mathrm{L}$ uranyl acetate were added to the shine side of the grid and allowed to stand for $1 \mathrm{~min}$ Excess uranyl acetate was removed by blotting the grid with a filter paper. The grid was then washed twice by dipping ten times into two separate containers of Millipore water. The grid was then placed on a filter paper, allowed to dry and then evaluated by TEM (Zeiss Libra 120) (Barreto-Vieira and Barth, 2015).

\section{Genotypic characterization}

Pure colonies were evaluated by $16 \mathrm{~S}$ rRNA gene sequencing (Genewiz Inc., South Plainfield, NJ), and sequences obtained were analyzed using NCBI 
Nucleotide

BLAST

search

(www.ncbi.nlm.nih.gov/blast/html/BLASThomehelp.html), and a phylogram generated utilizing MEGA 6.06 (bootstrapping, 1000). The 16S rRNA gene sequence was deposited in GenBank and assigned the accession number (KU495926).

The organism was also evaluated for the presence of plasmids by utilizing BIO 101 RapidPURETM Plasmid Mini Kit with turbo cartridges (North America, Europe), as well as Quigen plasmid extraction kit. Extraction was done following the manufacturer's instructions and the processed samples were assessed for the presence of plasmid DNA using 1\% agarose gel electrophoresis (Bio-Rad apparatus). Positive controls included 1000 base pair pUC8 (VWR International, Inc.), and Escherichia coli O157:H7 (ATCC 35150).

\section{Statistical analysis}

Microsoft Excel ${ }^{\circledR}, 2016$ was utilized to do Two-Factor ANOVA without replication on the data collected for spot and well-diffusion assays. This was utilized to access the significant difference between the zones of inhibition (obtained for both tests) for the organisms. Similarly, Pearson product correlation analysis was done to determine the association between spot and well-diffusion assay $(\alpha, 0.05)$. To evaluate flow cytometric data, two-way repeated measures ANOVA $(\alpha, 0.05)$ was done using SPSS v.23 (Statistical Package for Social Sciences) statistical software.

\section{RESULTS}

\section{Isolation and screening of LAB}

Antimicrobial activities against three indicator organisms Staphylococcus aureus (ATCC 6538), Listeria monocytogenes (ATCC 7644) and Escherichia coli
O157:H7 (ATCC 35150), were observed in a preliminary screening of lactic acid bacterial isolates selected from 15 samples of retail yogurt. Based on broad spectrum antimicrobial activity and predominance, only one of 59 isolates from yogurt, designated strain A1((KU495926)), was selected as a prototype for further characterization

\section{Phenotypic characterization of strain A1 ((KU495926))}

Cells were Gram-positive, catalase and oxidase negative, non-motile rods (singly or grouped) with length $(\sim 0.75$ to $2.75 \mu \mathrm{m})$ and width $(\sim 0.25$ to $0.75 \mu \mathrm{m})$. Electron micrographs reveal the presence of exopolysaccharide and another unidentified secreted particles (Figure 1). Isolated colonies on MRS agar plates were beige, umbonate, waxy, opaque and grew to approximately $2-4 \mathrm{~mm}$ diameter over 4 days' period. Colonies typically presented with irregular margins but occasional presentation of smooth margins was observed. The organism is facultative and heterofermentative. Carbon-dioxide was produced when grown in MRS broth, but no gas was detected in Durham tubes when grown in conventional glucose or maltose broth. It did not reduce nitrate nor liquefy gelatin. Acid was produced from several carbohydrates including lactose and 5keto-gluconate. It generated hydrogen sulfide gas in Kligler iron agar under both aerobic and anaerobic conditions, in Sulphur-Indole-Motility (SIM) under anaerobic conditions, but not in Lysine-Iron-Agar (LIA). It gave weakly positive, variable reaction in citrate under aerobic conditions in about 3 days, and cells grew at temperatures 25,37 and $45{ }^{\circ} \mathrm{C}$. The phenotypic characteristics of strain A1 (KU495626) are presented in Table 3. The predominant fatty-acid methyl esters identified were C16:0 (hexadecanoic acid, methyl ester), 38.3\% and C19: i10 (cis-10 nonadecenoic acid, methyl ester), 31.90\% (Table 4).

Table 3 Phenotypic characteristics of L. parafarraginis KU495926

\begin{tabular}{|c|c|c|c|}
\hline Characteristics & $\begin{array}{l}\text { Reaction } \\
\end{array}$ & Characteristics cont'd & Reaction \\
\hline Gram-stain & $\begin{array}{l}\text { Gram-positive rods (occurring singly or in } \\
\text { groups) }\end{array}$ & $\begin{array}{c}\text { Carbohydrate } \\
\text { Fermentation cont'd: }\end{array}$ & \\
\hline Oxidase & - & D-Mannose & + \\
\hline Catalase & - & L-Sorbose & - \\
\hline Gelatinase & - & L-Rhamnose & - \\
\hline Urease & - & Dulcitol & - \\
\hline Motility & - & Inositol & - \\
\hline Endospore & - & D-Mannitol & + \\
\hline FTM; O/F glucose; O/F lactose ${ }^{a}$ & Facultative anaerobe & D-Sorbitol & - \\
\hline Kliger iron agar & $\begin{array}{l}\text { Acid/Neutral with } \mathrm{H}_{2} \mathrm{~S} \text { at } 24 \mathrm{~h} ; \text { Acid/Acid with } \\
\qquad \mathrm{H}_{2} \mathrm{~S} \text { in 3-4 days }\end{array}$ & $\begin{array}{l}\text { Methyl- } \alpha \text {-D- } \\
\text { Mannosepyranoside }\end{array}$ & - \\
\hline Lysine Iron Agar (LIA) & Lysine decarboxylase - $\mathrm{H}_{2} \mathrm{~S}$ - & $\begin{array}{l}\text { Methyl- } \alpha-\mathrm{D}- \\
\text { Glucopyranoside }\end{array}$ & - \\
\hline Sulphur/indole /motility (SIM) & $\mathrm{H}_{2} \mathrm{~S}-/+^{\mathrm{b}}$, indole -, motility - & N-Acetylglucosamine & - \\
\hline Growth in MRS broth & $\begin{array}{l}+(\text { with gas production })^{c} \text {; heterofermentative. } \\
\text { Sediment formed at bottom of the tube; broth }\end{array}$ & Amygdalin & - \\
\hline Growth in Nutrient broth & $\begin{array}{c}\text { becomes } \\
\text { cloudy when tube is shaken, no flocculation } \\
\text { observed }\end{array}$ & Arbutin & - \\
\hline Growth on Mannitol Salt Agar & - & Esculin & + \\
\hline Citrate & $+_{w} /-^{d}$ & Salicin & - \\
\hline Nitrate & - & D-Cellobiose & - \\
\hline Methyl Red & + & D-Maltose & + \\
\hline Voges-Proskaur & - & D-Lactose & + \\
\hline Phenylalanine & - & D-Melibiose & + \\
\hline DNAse & - & Sucrose & + \\
\hline Growth at Different Temp: & & D-Trehalose & - \\
\hline $0^{0} \mathrm{C}$ & - & Inulin & - \\
\hline $4{ }^{0} \mathrm{C}$ & - & D-Melezitose & + \\
\hline $25{ }^{\circ} \mathrm{C}$ & + & D-Raffinose & + \\
\hline $37^{\circ} \mathrm{C}$ & + & Amidon(Starch) & - \\
\hline $45{ }^{\circ} \mathrm{C}$ & + & Glyocogen & - \\
\hline Carbohydrate Fermentation: & & Xylitol & - \\
\hline Glycerol & - & Gentiobiose & - \\
\hline Erythritol & - & D-Turanose & - \\
\hline D-Arabinose & - & D-Lyxose & - \\
\hline L-Arabinose & + & D-Tagatose & - \\
\hline D-Ribose & + & D-Fucose & - \\
\hline D-Xylose & + & L-Fucose & - \\
\hline L-Xylose & - & D-Arabitol & + \\
\hline D-Adonitol & - & L-Arabitol & - \\
\hline Methyl- $\beta$-D-Xylopyranoside & - & Gluconate & + \\
\hline D-Galactose & + & 2-Ketogluconate & - \\
\hline D-Glucose & + & 5-Ketogluconate & + \\
\hline D-Fructose & + & & \\
\hline
\end{tabular}

+, positive; + $+_{w}$, weakly positive; -, negative; $\mathrm{H}_{2} \mathrm{~S}$, Hydrogen Sulfide; +/-, variable; FTM, Fluid thioglycollate medium; ${ }^{\text {a }}$, Acid production in O/F lactose was faster than in $\mathrm{O} / \mathrm{F}$ glucose; ${ }^{\mathrm{b}}, \mathrm{H}_{2} \mathrm{~S}$ positive in SIM media under anaerobic but negative under aerobic conditions; ${ }^{\mathrm{c}}$, white precipitate formed when gas was bubbles into barium hydroxide solution (confirmed $\mathrm{CO}_{2}$ production and that the organism is heterofermentative); ${ }^{\mathrm{d}}$, Weakly positive reaction in citrate observed at 3-4 days under aerobic conditions. 
Table 4 Major fatty acid methyl esters (FAME) derived from strain A1 ((KU495926)) and MRS agar (control) identified by Gas chromatography mass spectrometry (GC/MS)

\begin{tabular}{lccccccc}
\hline & \multicolumn{7}{c}{ Fatty Acid Methyl Ester (\%) } \\
\hline & C16: i9 & C16:0 & C18: i9 & C18:0 & C18:0 & C14:0 & C19: i10cis \\
\cline { 2 - 7 } A1 & $\mathbf{0 . 9 2}$ & 38.30 & 6.09 & 3.43 & 3.43 & $\mathbf{0 . 2 6}$ & 31.90 \\
MRS Agar (control) & & 2.04 & $\mathbf{8 . 2 5}$ & $\mathbf{0 . 9 4}$ & & & \\
\hline
\end{tabular}

Key: (left to right across heading of the table) :>9- Hexadecenoic acid, methyl ester (C16:i9), (Z)- Hexadecanoic acid, methyl ester(C16:0),9-Octadecenoic acid (Z)-,methyl ester (C18:i9), Octadecanoic acid, methyl ester (C18:0)>Methyl stearate (C18), Methyl tetradecanoate (C14:0),> cis-10-Nonadecenoic acid, methyl ester (C19:110 cis).

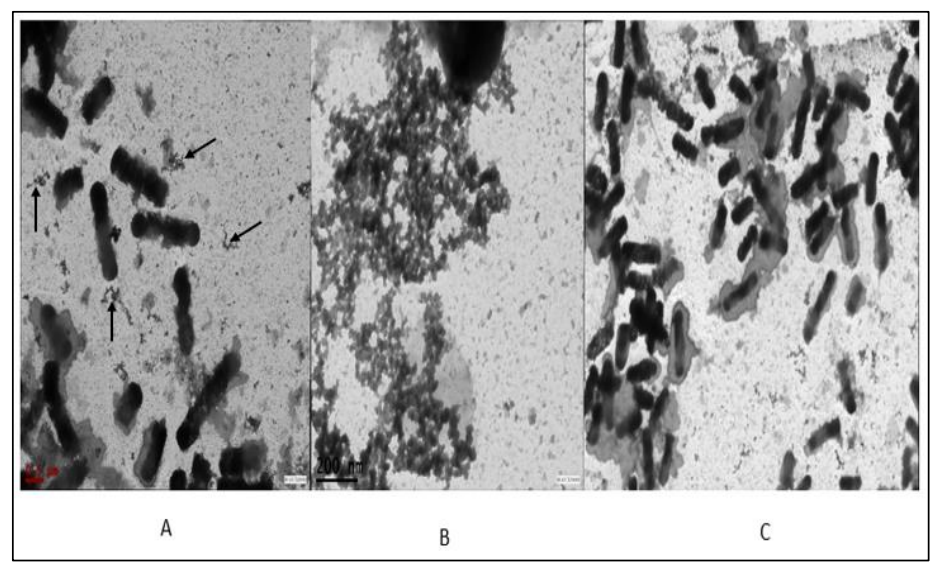

Figure 1 Shows three electron micrographs of Lactobacillus parafarraginis (KU495926). A, the bacillary structure of this lactic acid bacteria along with numerous particles suspected to be secreted bacteriocins in the field (see arrows in micrograph). B, increased magnification $(50,000 \times)$ of potential secreted bacteriocin. $\mathbf{C}$, bacilli covered in mucoid material, suggesting exopolysaccharide production by the bacilli. The dimensions of the bacilli were estimated to be: $\sim 0.75-2.75 \mu \mathrm{m} \times \sim 0.25-0.75 \mu \mathrm{m}$.

The bacilli have an estimated generation time of $5.4 \mathrm{~h}$ and $3.04 \mathrm{~h}$ respectively in MRS broth under aerobic and anaerobic conditions (Figure 2. (a) and (b) and Equation 1). Growth is best in $0.5 \% \mathrm{NaCl}$ when compared to $6.5,10$ and $15 \%$ (Figure 2. (c)). The bacilli were however halotolerant as they survived in $10 \%$ $\mathrm{NaCl}$ for $75 \mathrm{~h}$. When inocula from each $\mathrm{NaCl}$ concentration were incubated in MRS broth and then plated on MRS agar plates growth was obtained on all plates excepting plates streaked with inocula related to $15 \% \mathrm{NaCl}$. Strain A1 (KU495926) was also found to grow best under acidic conditions ( $\mathrm{pH} 3$ ) when compared to $\mathrm{pH} 7$ and $\mathrm{pH} 9$ (Figure 2. (d)).

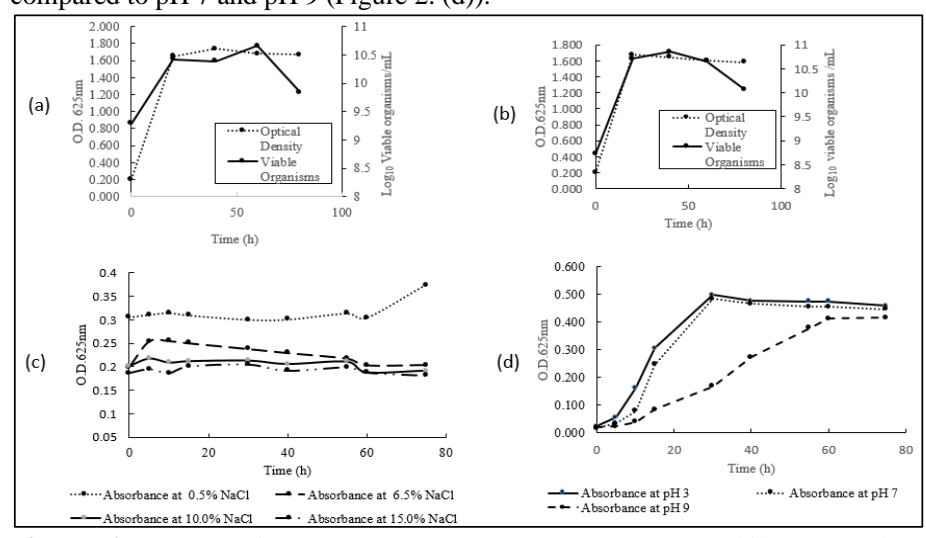

Figure 2 Growth of $L$. parafarraginis ((KU495926)) under different physical conditions; (a) and (b) show growth in MRS broth under aerobic and anaerobic conditions respectively; (c) Optical density of growth in nutrient broth of different percent concentration of sodium chloride $(0.5,6.5,10.0$ and $15.0 \%)$. (d) Growth in nutrient broth of different $\mathrm{pH}(3,7$ and 9$)$.

\section{Equation 1 Calculations of Generation Time}

Using the equation from (Madigan et al., 2012),

Where: $g=t / n ; \mathrm{g}=$ generation time of the exponential growing population; $t=$ time taken to give rise to $n$ generations; $n=$ number of generations during the period of exponential growth. $n=3.3\left(\log N-\log N_{0}\right)$ Where: $N=$ final cell number, $N_{0}=$ initial cell number Where:

$N=N_{0} 2 n$

$\log N=\log N_{0}+n \log 2$

$\log N-\log N_{0}=n \log 2$

$n=\log N-\log N_{0} / \log 2$; $n=\log N-\log N_{0} / 0.301$

$n=3.3\left(\log N-\log N_{0}\right)$

Generation time under aerobic conditions: $g=t / n ; g=20 \mathrm{~h} / 3.3 \times \log$ $\left(10^{10.419} / 10^{9.290}\right) ; g=20 \mathrm{~h} / 3.3 \times 1.129 ; \mathrm{g} \sim 5.4 \mathrm{~h}$

Gener ${ }_{a}$ tion time under anaerobic conditions: $g=t / n ; g=20 \mathrm{~h} / 3.3 \times \log$ $\left(10^{10.712} / 10^{8.716}\right) ; g=20 \mathrm{~h} / 3.3 \times 1.996 ; g \sim 3.04 \mathrm{~h}$

\section{Genotypic characterization of strain A1 (KU495926)}

Strain A1 (KU495926) was initially identified by API $50 \mathrm{CH}$ as $99.9 \%$ similar to Lactobacillus brevis; however, NCBI BLAST of 16S rRNA gene sequence showed a $99 \%$ similarity to $L$. parafarraginis strain NRIC 0677 . This was further supported by MEGA6.06 (100\% identity). As shown by the phylogenetic tree (Figure 3), there is no close alignment with Lactobacillus brevis.

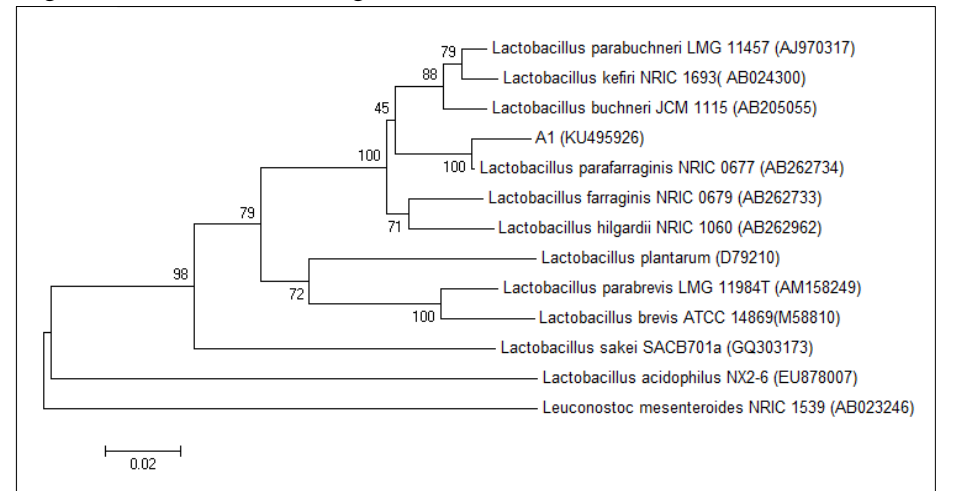

Figure 3 Phylogenetic tree generated by utilizing the software MEGA 6.06 (bootstrapping, 1000×), shows that among several different species of lactobacilli, strain A1 (KU495926) is more closely related to L. parafarraginis.

\section{Inhibitory action of $L$. parafarraginis (KU495926)}

Lactobacillus parafarraginis (KU495926) inhibited fourteen multidrug-resistant and extended spectrum $\beta$-lactamase Gram-negative clinical isolates. These include Escherichia coli (5), Pseudomonas aeruginosa (2), Acinetobacter baumannii (3), Enterobacter aerogenes (1), Proteus mirabilis (2) and Klebsiella pneumoniae (1), as well as eleven other pathogens (Table 5, Figure 4). Twofactor ANOVA without replication showed that there was no statistical significance among the average zones of inhibition for the indicator organisms $(F$ $(24,24)=1.53 ; p=0.15)$. There was however a significant difference between the average zones of inhibition for spot and well-diffusion assay $(F(1,24)=115.09$; $p<0.05)$. Pearson correlation analysis however, showed a positive association between spot and well-diffusion assay $\left(\mathrm{r}=0.3 ; \mathrm{r}^{2}=9 \%\right)$, (Figure 5).

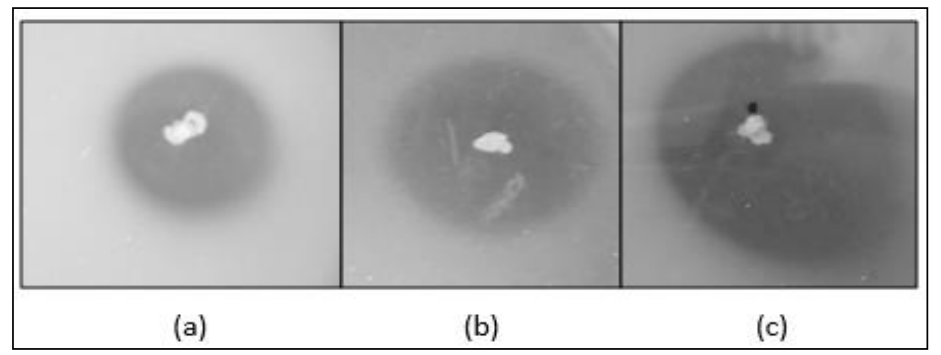

Figure 4 Photograph of three spot-tests illustrating the inhibitory action of $L$. parafarraginis (KU495926); (a) Inhibition of K. pneumoniae (HUH09), (b) inhibition of S. pyogenes ATCC 12384, and (c) Inhibition of $A$. baumannii/haemolyticus (HUH11). 
Table 5 Average zones of inhibition exhibited by L. parafarraginis KU495926 in spot-test and well-diffusion assays against twenty-five indicator organisms.

\begin{tabular}{|c|c|c|}
\hline & Spot-Test Assay $^{*}$ & Well-Diffusion Assay $^{*}$ \\
\hline Indicator Organisms & $\begin{array}{c}\text { Average Zones of } \\
\text { inhibition }(\mathbf{m m})\end{array}$ & $\begin{array}{c}\begin{array}{c}\text { Average Zones } \\
\text { of inhibition } \\
(\mathbf{m m})\end{array} \\
\end{array}$ \\
\hline Pseudomonas aeruginosa (culture collection) ${ }^{\ddagger}$ & 46.5 & 15.0 \\
\hline Serratia marcescens (culture collection) ${ }^{\ddagger}$ & 34.5 & 12.3 \\
\hline Shigella sonnei ATCC 1060 & 31.3 & 12.3 \\
\hline Yersinia enterocolitica ATCC 23715 & 32.3 & 16.8 \\
\hline Streptococcus pyogenes ATCC 12384 & 30.3 & 11.8 \\
\hline Escherichia coli O157:H7 ATCC 35150 & 36.0 & 17.0 \\
\hline Bacillus cereus (culture collection) & 28.3 & 10.0 \\
\hline Enterococcus faecalis ATCC 29212 & 19.0 & 11.0 \\
\hline Staphylococcus aureus ATCC 6538 & 19.5 & 16.8 \\
\hline Staphylococcus aureus (culture collection) ${ }^{\ddagger}$ & 21.5 & 18.3 \\
\hline Listeria monocytogenes ATCC 7644 & 28.5 & 16.0 \\
\hline Proteus mirabilis $(\mathrm{HUH} 01)^{\mathrm{b}}$ & 23.3 & 15.8 \\
\hline Pseudomonas aeruginosa $(\mathrm{HUH} 02)^{\mathrm{a}}$ & 35.0 & 14.0 \\
\hline Proteus mirabilis $(\mathrm{HUH} 03)^{\mathrm{a}}$ & 28.3 & 11.5 \\
\hline Acinetobacter baumannii/haemolyticus $(\mathrm{HUH} 04)^{\mathrm{a}}$ & 23.8 & 11.8 \\
\hline Escherichia coli $(\mathrm{HUH} 05)^{\mathrm{b}}$ & 27.0 & 10.0 \\
\hline Pseudomonas aeruginosa $(\mathrm{HUH} 06)^{\mathrm{a}, \mathrm{c}}$ & 27.3 & 17.0 \\
\hline Escherichia coli $(\mathrm{HUH} 07)^{\mathrm{a}, \mathrm{b}}$ & 24.8 & 11.8 \\
\hline Acinetobacter baumannii/ haemolyticus (HUH08) ${ }^{\mathrm{a}, \mathrm{c}}$ & 39.0 & 20.0 \\
\hline Klebsiella pneumoniae ( $\mathrm{HUH} 9^{\mathrm{a}, \mathrm{b}}$ ) & 14.8 & 10.8 \\
\hline Enterobacter aerogenes $\left(\mathrm{HUH} 10^{\mathrm{a}}\right)$ & 20.3 & 11.5 \\
\hline Acinetobacter baumannii/haemolyticus (HUH11) & 28.5 & 10.0 \\
\hline Escherichia coli $(\mathrm{HUH} 12)^{\mathrm{a}, \mathrm{b}}$ & 28.5 & 13.5 \\
\hline Escherichia coli (HUH13) ${ }^{\mathrm{a}, \mathrm{c}}$ & 29.3 & 14.0 \\
\hline Escherichia coli (HUH144, $)$ & 23.3 & 14.0 \\
\hline
\end{tabular}

a, MDR; ${ }^{\mathrm{b}}$, ESBL; ${ }^{\mathrm{c}}$, Carbapenem resistant (Carbapenem resistance is highlighted here in addition to MDR and ESBL as the carbapenems are usually the
antibiotic treatment of last resort for many infections caused by Gram-negative bacteria); $\downarrow$, Culture collection Dr. B.E. Eribo (Howard University, Biology Department); † Isolated from clinical specimens at local Washington D.C. Hospital; ¥ An average of four (4) readings. Isolation sites: HUH01 = Incision; HUH02, HUH03, HUH04, HUH07 \& HUH13 = Urine; HUH14 = Urinary Bladder; HUH05 and HUH08 = Sacral decubitus; HUH06 = Right ankle; HUH11 \& HUH12 = Wound; HUH 09 = Peripheral blood

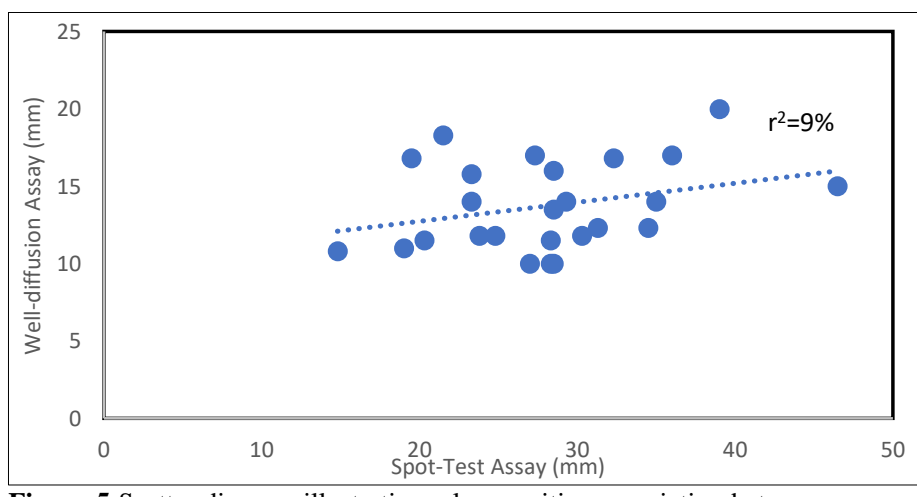

Figure 5 Scatter diagram illustrating a low positive association between average zones of inhibition of spot-test and well-diffusion assays for twenty-five indicator organisms.

Time lapse studies done with $P$. aeruginosa (HUH06) using fluorescence microscopy and aerobic plate counts showed a sharp reduction in the number of organisms alive in the presence of L. parafarraginis ((KU495926)) CFS by $24 \mathrm{~h}$ of exposure when compared to the control (MRS broth), (Figure 6). A similar observation was made with Acinetobacter baumannii (HUH11). Flow cytometric analyses with E. coli (HUH12), P. aeruginosa (HUH06) and Acinetobacter baumannii (HUH08), showed that the number of organisms alive at times $5 \mathrm{~h}$ and $96 \mathrm{~h}$ in the presence of $L$. parafarraginis (KU495926) CFS decreased when compared to the control (Figure 7). Further analysis using ANOVA indicated a significant difference between the overall average number of organisms alive in L. parafarraginis (KU495926) CFS when compared to control, $(F(1,2)=$ 77.067; $p=0.013 ; \alpha=0.05)$.

The minimum inhibitory concentration (MIC) of L. parafarraginis (KU495926) lyophilized CFS was $\sim 20 \mathrm{mg} / \mathrm{mL}$, and the minimum bactericidal concentration $(\mathrm{MBC})>20 \mathrm{mg} / \mathrm{mL}$.

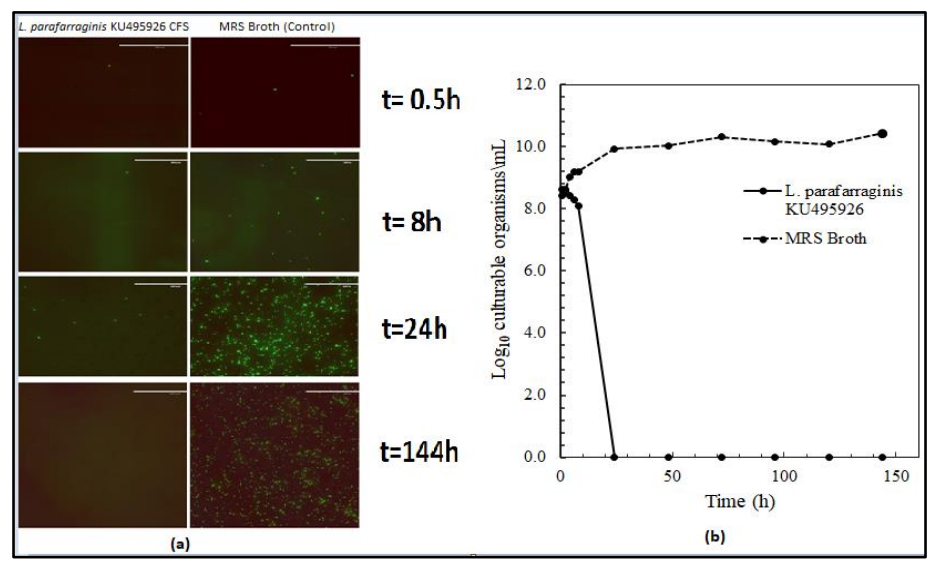

Figure 6 EVOS fluorescence microscopy in parallel with standard plate count (A) Fluorescence microscopy (Magnification: 200X) and (B) aerobic plate count showing decreased number of viable $P$. aeruginosa (HUH06) with time in $L$. parafarraginis KU495926 CSF when compared with the control experiment (MRS broth). Similar results were obtained with Acinetobacter baumannii/haemolyticus (HUH11). 


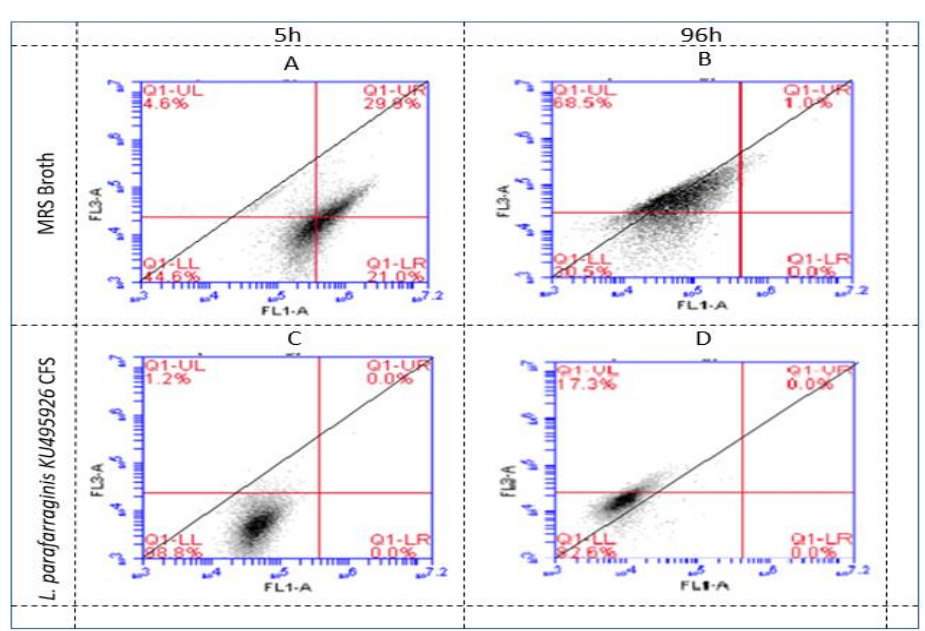

Figure 7 Flow cytometric analyses of multidrug-resistant E. coli (HUH12) exposed to MRS broth (control) and cell free supernatant (CFS) of $L$. parafarraginis KU495926. Tested for 5h (A \& C) and 96h (B \& D). Channel FL1-A recorded the dye SYTO9 which tagged live organisms and channel FL3-A the dye propidium iodide which tagged dead organisms. The diagonal lines drawn in the graphs are reference lines. Organisms below the reference lines are considered alive and those above are considered dead. Similar results were obtained using $P$. aeruginosa (HUH06) and A. baumannii /haemolyticus (HUH08)

\section{Growth Curve and Bacteriocin Production.}

SDS-PAGE of CFS collected at different times appoints, over growth curve for $L$ parafarraginis (KU495926), showed the appearance of a protein band between 75 to $100 \mathrm{kDa}$ during the exponential growth phase at time $15 \mathrm{~h}$, (Figure 8a). This protein band persisted for the entire period of $96 \mathrm{~h}$ over which the experiment was conducted The highest activity (unit/mL) occurred during the late exponential growth phase, $21 \mathrm{~h}$ (Figure 8b). These findings correlated with aerobic plate count, which showed that at $15 \mathrm{~h}$ (average $\mathrm{pH}, 4.7075)$, E. col (HUH14) presented dimorphic colonies (medium and pinpoint sizes; both morphotypes were identified as E. coli by API 20E) and no E. coli (HUH14) colony grew on the plates starting at incubation with CFS collected at $21-60 \mathrm{~h}$ (Figure 8c). Checks of average $\mathrm{pH}$ changes along the growth curve (Figure 8d) revealed that the time of maximum activity correlated with the lowest average $\mathrm{pH}$ recorded at $21 \mathrm{~h}$ (average $\mathrm{pH}, 4.1075$ ). This $\mathrm{pH}$ remained relatively constant until there was a slight increase at time $72 \mathrm{~h}$ (average $\mathrm{pH}, 4.32$ ). Although the average $\mathrm{pH}$ at $72 \mathrm{~h}$ was similar to the average $\mathrm{pH}$ at $18 \mathrm{~h}$ (average $\mathrm{pH}, 4.38$ ) a significantly lower number of colonies grew in CFS collected at $72 \mathrm{~h}$ when compared to CFS collected at $18 \mathrm{~h}, 3.67 \times 10^{2} \mathrm{CFU} / \mathrm{mL}$ and $3.33 \times 10^{5} \mathrm{CFU} / \mathrm{mL}$ respectively.
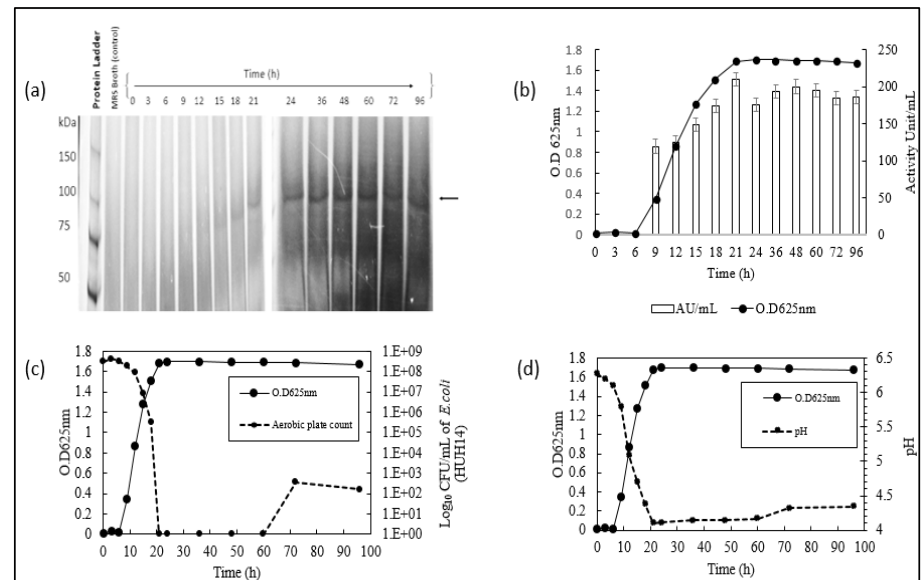

Figure 8 Time lapse study of bacteriocin synthesis along a 96h growth curve of L. parafarraginis KU495926; (a) SDS-PAGE done using CSF collected at different times $(0,3,6,9,12,15,18,21,24,36,48,60,72$, and $96 \mathrm{~h})$ along the growth curve of $L$. parafarraginis KU49592 to identify time and $\mathrm{pH}$ of optimum bacteriocin synthesis. The first two lanes show protein ladder and plain MRSbroth (control) respectively. The arrow to the right points to the position of the appearance of a protein band between 75-100 kDa; (b) shows activity unit $/ \mathrm{mL}$ of concentrated CFS collected during the exponential and stationary phase of growth; Maximum activity was seen at $21 \mathrm{~h}$; (c) aerobic plate count of $E$. coll (HUH14) with CFS collected at different times along the growth curve of $L$. parafarraginis KU49592; (d) shows changes in $\mathrm{pH}$ with time along the growth curve during bacteriocin synthesis.

\section{Effect of temperature pH and enzymes on the inhibitory actions of CFS}

The CFS of $L$. parafarraginis retained activity post temperature treatments of 40 , 80 and $100^{\circ} \mathrm{C}$ and $121^{\circ} \mathrm{C}(20$ min under $15 \mathrm{psi})$. Highest inhibitory activity was also indicated under acidic conditions ( $\mathrm{pH} 2$ and 4.5) (Figure 9). Exposure of active FPLC fractions to the enzymes pepsin, papain, trypsin, $\alpha$-chymotrypsin and proteinase $\mathrm{K}$ did not result in a loss of inhibitory action. The CFS also retained activity when treated with trypsin, pepsin, $\alpha$ - chymotrypsin, $\alpha$-amylase, proteinase K, peptidase, lipase A and catalase.

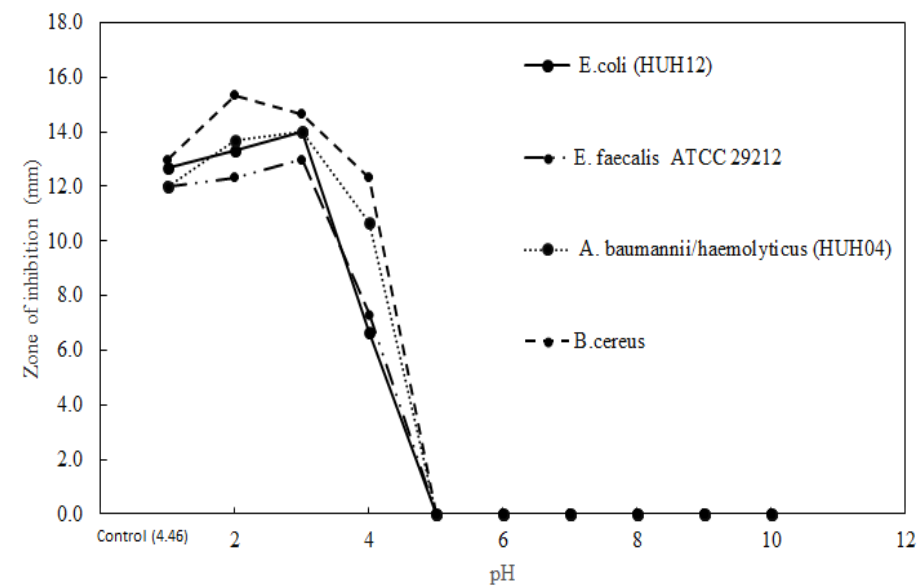

Figure 9 The activity of $L$. parafarraginis (KU495926) CFS at different $\mathrm{pH}$ against four indicator organisms: E. coli (HUH12), E. faecalis (ATCC 29212), A. baumannii/haemolyticus (HUH04) and B. cereus. Maximum activity was seen under acidic conditions (about $\mathrm{pH} 2$ to 4.5 ).

\section{Identification and partial purification of bacteriocin(s) produced by $L$. parafarraginis (KU495926)}

No plasmid was found in L. parafarraginis (KU495926) and so the bacterial DNA was utilized in PCR analysis for bacteriocin structural genes. PCR detected the presence of four bacteriocin structural genes, namely $\operatorname{sakT}-\beta$, sakT- $\alpha ; \operatorname{pln} c 8 A$ and $a c d T$ (Figure 10). The DNA sequences obtained for $s a k T-\beta, s a k T-\alpha$ and $a c d T$ had high trace scores of 57,49 and 46 respectively, while that of $p \ln C 8 A$ had a

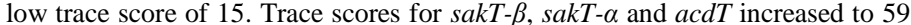
53 , and 51 respectively following analysis with $\mathrm{ABI}$ sequence scanner, however the score for $\operatorname{plnc} 8 A$ remained the same. Pairwise comparisons of the DNA

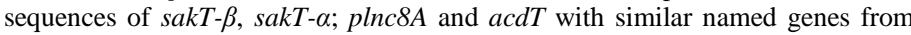
GenBank (see Materials and Methods) showed 46, 48, 32 and 46\% identity respectively. BLASTX revealed a high probability that the conceptual translation products of the DNA sequences shared biologically meaningful relationships as follows: $s a k T-\beta, 98 \%$ identity with Holliday junction branch migration protein RuvA (Lactobacillus parafarraginis DSM 18390), E-value, $6 \times 10^{-76}$; sakT- $\alpha$, $100 \%$ identity to L-arabinose isomerase (Lactobacillus parafarraginis), E-value, $4 \times 10^{-51} ;$ acdT, $100 \%$ identity to $\mathrm{N}$-acetyltransferase (Lactobacillus parafarraginis), E-values $1 \times 10^{-4}$ and $2 \times 10^{-4}$; plnc $8 A, 35 \%$ identity to glycosyl hydrolase family 2 , sugar binding domain protein (Lactobacillus parafarraginis F0439), E-value $6 \times 10^{-4}$. In silico analyses of the sequenced bacteriocin structural genes using the bacteriocin mining tool BAGEL3 identified thirteen Areas of Interests (AOIs) in five bacterial reference chromosomes screened $(L$. buchneri CD034, L. acidophilus 30SC, L. acidophilus-La14, L. acidophilus NCFM and L. plantarum subsp. plantarum P8). All AOIs were common to all the sequences analyzed excepting one $\mathrm{AOI}$ in $L$. acidophilus $30 \mathrm{SC}$ which was only common to the sequences for $s a k T-\alpha$ and $a c d T$. Among the thirteen AOIs, twenty- three putative bacteriocin/ modified peptide hits were made. Eleven hits predicted putative bacteriocin/modified peptide associated with the Class III bacteriocins $(>10 \mathrm{kDa})$, helveticin $\mathrm{J}$ or enterolysin A. Ten hits predicted associations with Class II bacteriocins/glyocin, namely acidocin J1132 beta peptide_N terminal, LS2 chain, thermophilin A, amylovorin, plantaricin_E and lactacin_F subunit. There was also one hit that indicated association with unmodified head_tail_cyclized peptide. Putative bacteriocin associated genes for regulation were identified in one AOI, transport and leader cleavage genes in four AOIs and immunity/transport genes in nine AOIs. 


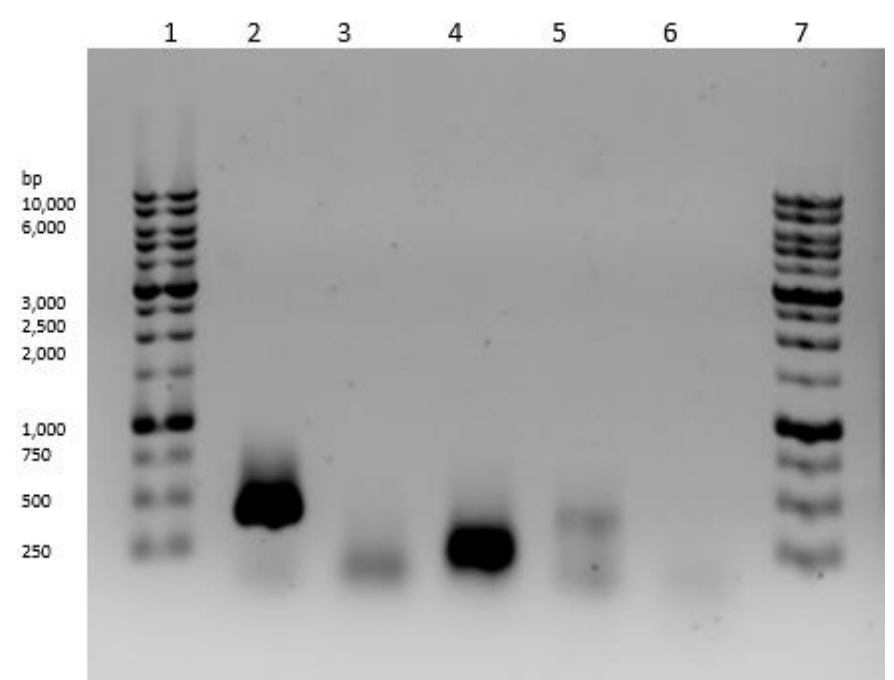

Figure 10 Agarose gel electrophoresis of PCR amplicons of specific bacteriocin structural genes. Lane 1 and 7: DNA Ladder (250-10,000 bp); Lane 2: sakT- $\beta$; Lane 3: sakT- $\alpha$; Lane 4: acdT; Lane 5: plnc $8 \mathrm{~A}$ and Lane 6: plnc $8 B$ (no amplification observed)

SDS-PAGE detected the presence of varying numbers of protein bands in the CFS from the organism, with the numbers increasing with age of the CFS. More protein bands were evident in gels stained with imidazole-SDS-Zinc when compared to Coomassie Blue R250 (Figure 11). The $\sim 72 \mathrm{~h}$ CFS of $L$. parafarraginis (KU495926) (having the least number of protein bands) inhibited the growth of all the indicator organisms (Table 5). All aged CFS however had inhibitory activity. For the $\sim 72 \mathrm{~h}$ CFS Coomassie blue R250 (Figure 11(a)) indicated the presence of a single prominent protein band at $\sim 75 \mathrm{kDa}$, however use of imidazole- zinc- SDS (Figure 11 (b)) showed the presence of other protein bands: approximately 48,63 and $>240 \mathrm{kDa}$. FPLC of speed vacuum concentrated $\sim 72 \mathrm{~h}$ CFS, pooled based on peak cut-off and SDS-PAGE analysis yielded an active fraction containing a prominent protein band between 75 and $100 \mathrm{kDa}$ (Figure 12). It is also noteworthy that for L. parafarraginis FPLC active fractions (1 and 2) (Figure 12) there also appeared a band $\sim 35 \mathrm{kDa}$ (lanes 2 and $3)$.

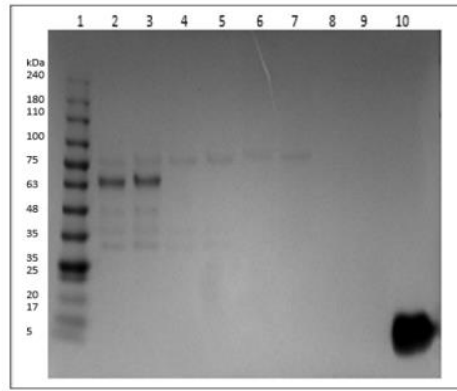

(a)

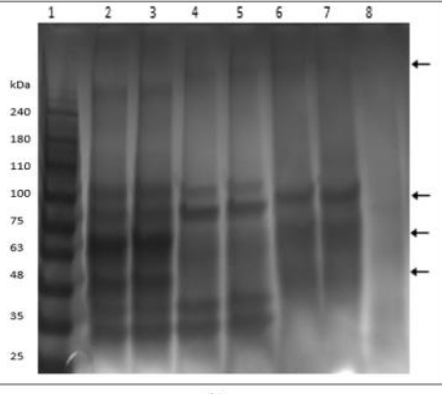

(b)
Figure 11 SDS-PAGE of $L$. parafarraginis (KU495926) cell free supernatant (CFS) showing bands of proteins (possibly bacteriocins) released by the organism; (a) Stained with Coomassie blue R250 and (b) stained with Imidazolezinc-SDS. The same substances were electrophoresed in lanes with same numbers. Lane1: Protein Ladder (5-240 kDa); Lanes 2-3: CFS from 5 months refrigerated $\left(6^{0} \mathrm{C}\right)$ culture; Lanes 4-5: CFS from 3 months refrigerated $\left(6^{\circ} \mathrm{C}\right)$ culture; Lanes 6-7: CFS from 72 hours $\left(37^{\circ} \mathrm{C}\right)$ culture; Lanes 8-9: MRS broth only and Lane 10: A known bacteriocin nisin. Inhibitory activity via welldiffusion assays was observed utilizing (CFS) of all ages against the screening indicator organism $S$. aureus. The 72h sample was used in well- diffusion assay to inhibit the growth of the indicator organisms in Table 5.

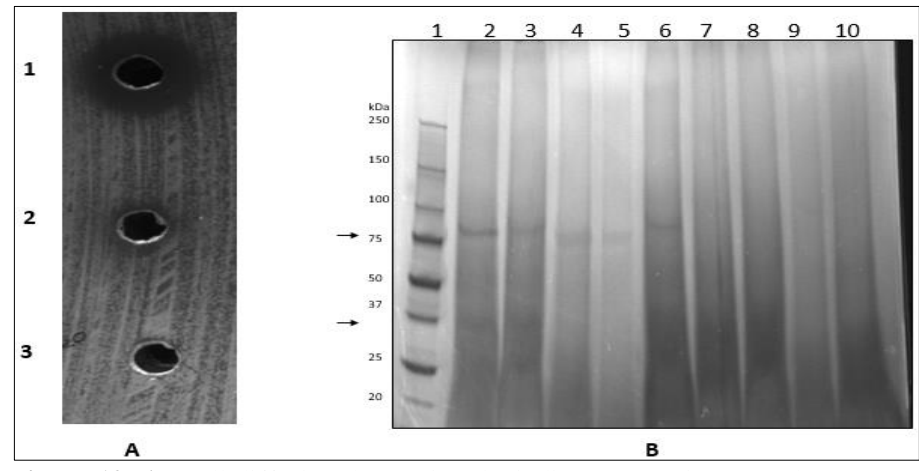

Figure 12 (A) well-diffusion done using the indicator organism E. coli (HUH14) on trypticase soy agar: 1. Inhibition of E. coli (HUH14) by FPLC active fractions obtained from 72h CFS of L. parafarraginis (KU495926), 2. Assay done with FPLC corresponding FPLC fractions of the control MRS broth and 3. shows assay done by using sterile $\mathrm{pH} 4.43$ deionized water added to assayed samples.(B) SDS-PAGE done with FPLC active fractions; Lane1= BioRad Precision Plus protein ladder ; Lanes 2-6 FPLC fractions from $L$ parafarraginis (KU495926) CFS shows presence of prominent protein bands $\sim 75 \mathrm{kDa}$; a paler band is also evident $\sim 35 \mathrm{kDa}$ (Lanes 2 and 3). Lanes 7 - 10 are corresponding fractions from the control MRS broth.

\section{DISCUSSION}

In this study a Lactobacillus species, strain A1 (KU495926) was isolated from a sample of commercial yogurt and inhibited the growth of fourteen MDR/ESBL Gram-negative bacteria from clinical source. It was identified by API $50 \mathrm{CH}$ and phylogenetic analyses of its $16 \mathrm{~S}$ rRNA gene sequence. API 50CH identified strain A1 (KU495926) as $99.9 \%$ similar to L. brevis, while NCBI-BLAST search and phylogenetic alignment using its $16 \mathrm{~S}$ rRNA gene sequence demonstrated the isolate was 99 and $100 \%$, similar to L. parafarraginis. The isolate was therefore designated L. parafarraginis (KU495926), as ascertaining the identity of bacteria by genotypic methods such as $16 \mathrm{~S}$ rRNA gene sequencing, is usually more accurate than phenotypic testing such as API 50CH (Dimitonova et al., 2008; C M. Lee et al., 2008; Moraes et al., 2013). The bacilli presented the typical phenotypic characteristics of a Lactobacillus species in being Gram-positive, facultative, catalase and oxidase negative, non-motile, asoporogenous, gelatinase and nitrate reductase negative and acidophilic. Lactobacillus parafarraginis (KU495926) is also heterofermentative and halotolerant with generation time of $\sim 3.04$ and $\sim 5.4 \mathrm{~h}$ under anaerobic and aerobic conditions respectively.

To date, only two publications have identified the phenotypic characteristics of the species L. parafarraginis (Endo and Okada, 2007; Liu et al., 2014). Our data support previous findings, wherein, L. parafarraginis (KU495926) produces acid from L-arabinose, D-ribose, D-xylose, D-galactose, D-glucose, D-fructose D-maltose, D-mannitol, D-melibiose, sucrose, D-melezitose, D-raffinose and gluconate(Endo and Okada, 2007; Liu et al., 2014). While Endo and Okada reported no acid from lactose nor mannose, this research reports acid production from both lactose and D-mannose, which supports previous findings (Liu $\boldsymbol{e t}$ al. 2014). The usage of conventional tube media, (broth), under aerobic conditions does not result in lactose fermentation. However, usage of conventional tube media, (with agar), yielded positive lactose results under both aerobic and anaerobic conditions, and occurs at a faster pace anaerobically, and the usage of $\mathrm{O} / \mathrm{F}$ lactose by the bacilli occurred faster than $\mathrm{O} / \mathrm{F}$ glucose. The latter observation suggests that a faster growth rate with lactose, rather than glucose, may occur due to the characteristics of the transporters involved in glucose or lactose uptake (Chervaux et al., 2000). Additionally, the proposal was made that although this phenomenon contrasts the general idea that glucose is the hierarchically preferred sugar for bacteria, they can adapt to a given growth medium. Considering that $L$. parafarraginis (KU495926) was isolated from a milk product, (yogurt), it may have adapted to using lactose as a substrate. This ability could make this isolate an excellent probiotic alternative for individuals with lactose intolerance.

Unusual phenotypic characteristics of L. parafarraginis (KU495926) included acid production from 5-ketogluconate, $\mathrm{H}_{2} \mathrm{~S}$ production in Kliger ion agar and presence of fatty acid methyl ester C19: i10 cis (nonadecenoic acid, 31.9\%) (Table 2). Currently, research in examining cis-10-nonadecenoic acid is sparse; however, Gao et al. 2012, reported finding cis- 10-nonadecenoic acid in the spores of the Chinese medicinal mushroom Ganoderma lucidum and indicated that it possesses anti-tumor properties. The size of $L$. parafarraginis (KU495926), ( $\sim 0.75$ to $2.75 \mu \mathrm{m} \times \sim 0.25$ to $0.75 \mu \mathrm{m})$ suggests that the bacilli can present width below the generally accepted $0.5 \mu \mathrm{m}$ for the genus Lactobacillus (Holt et al., 1994). Furthermore, the arrangement of the bacterial cells as groups rather than in chains is unlike the strains reported by Endo and Okada (2007). To the best of our knowledge, this study presents the first electron micrographs of $L$. parafarraginis species. Interest in obtaining an electron micrograph of the organism was stimulated by work published by Daw et al. (1996) which stated that knowledge about bacteriocins leaned heavily on results obtained by electron microscopic studies used to describe the morphology and the killing process of 
bacteriocin particles (Daw and Falkiner, 1996). Therefore, in attempting to visualize bacteriocin secreted by L. parafarraginis (KU495926) it was grown for an extended period in culture (12 days) to allow secreted peptides to accrue Electron micrographs showed the presence of particles dispersed in the field adjacent to the bacilli. These particles may be bacteriocins secreted by the bacilli. The secretion of an exopolysaccharide by L. parafarraginis (KU495926) adds to knowledge governing approximately 30 species of exopolysaccharide producing lactobacilli (Badel et al., 2011). One of the most described applications of exopolysaccharide production by lactobacilli is its utilization as texturing agents naturally synthesized in fermented foods (Badel et al., 2011).

The inhibitory activity of L. parafarraginis (KU495926) is atypical, as it is the conventional wisdom that bacteriocins from lactic acid bacteria only inhibit the growth of other Gram-positive bacteria (Abee et al., 1995; Gillor et al., 2008; Heng et al., 2007; Klaenhammer, 1988; M. Riley and Gillor, 2007). However, a few studies do not support this phenomenon (Mlalazi et al., 2011; Muller $\boldsymbol{e}$ al., 2009; Todorov and Dicks, 2005). In the current study, a broad spectrum antimicrobial activity was observed against MDR/ESBL Gram-negative bacteria and other bacterial species in both spot and well diffusion assays. Pearson's correlation analysis showed a positive association between spot and welldiffusion assay; ANOVA showed that there was a significant difference between the zones of inhibition from direct differed antagonism by $L$. parafarraginis (KU495926) via spot test assay when compared to well-diffusion assay. The latter data suggest that in the presence of the L. parafarraginis (KU495926) the killing of the pathogens is greater than with its CFS generated in MRS broth Further evaluation using EVOS fluorescence microscopy /aerobic plate count studies and flow cytometry with selected MDR/ESBL Gram-negative bacteria, $P$. aeruginosa (HUH06), Acinetobacter baumannii/haemolyticus (HUH11) and $E$ coli (HUH12) also confirmed the inhibitory activity of $L$. parafarraginis (KU495926).

The inhibitory agent produced by $L$. parafarraginis (KU495926), was heat stable; causes a change in bacterial phenotype, is acidophilic and may have weight of $\sim 75 \mathrm{kDa}$. The dramatic shift in colony morphology of pathogens such as E. coli (HUH14), from large to pinpoint colonies is strongly suggestive that the colony forming units suffered damage, and were unable to divide in a prolific manner. It is noteworthy to mention that work done by Liu et al. 2014 indicated that $L$. parafarraginis $\mathrm{ZH} 1$ produced other inhibitory substances in addition to organic acids as though acid production decreased at $15^{\circ} \mathrm{C}$, it was sufficient to inhibit yeasts. In this study, the data suggest that in addition to organic acids, $L$. parafarraginis (KU495926) produced inhibitory substance(s) that is/are bacteriocin-like. It is known that some bacteriocins are not secreted as bioactive peptides and require further extracellular processing by a general/specific protease or they possess Asp-Pro bonds that are easily hydrolyzed under acidic conditions to give the active form of the bacteriocin (Kemperman et al., 2003) The latter observation suggests a possible explanation for the observations made concerning the maximum antimicrobial activity observed under acidic conditions It is also known that a classic bacteriocin such as nisin is dramatically influenced by $\mathrm{pH}$. Its solubility, stability and biological activity drop as the $\mathrm{pH}$ increase. Irreversible inactivation of nisin resulting in its denaturation can occur above $\mathrm{pH}$ 7, but it shows maximum stability at $\mathrm{pH} 3$ (M. Riley and Gillor, 2007)

Polymerase chain reaction detected the presence of four bacteriocin structural genes in the chromosome of $L$. parafarraginis (KU495926): (sakT- $\beta$ ) for sakacinT- $\beta$ chain, $(\operatorname{sakT}-\alpha)$ for sakacinT- $\alpha$ chain, (acd T) for acidocin and (plnc $8 A$ ) for plantaricin- $\alpha$ chain. These results suggests that $L$. parafarraginis (KU495926) has multiple bacteriocin producing potential and correlated with the finding that in addition to a band $\sim 75 \mathrm{kDa}$, L. parafarraginis (KU495926) can generate several peptides, varying in numbers depending on its period of growth and type of staining technique utilized for visualization. Although the bacteriocin structural genes detected encodes small molecular weight peptides and SDSPAGE detected high molecular weight peptides, it is common knowledge that some bacteriocins initially thought to be large complex molecules or of highe molecular weights in culture CFS were further purified as smaller peptides (Cleveland et al., 2001; Klaenhammer, 1988). In this study, it was found that the CFS of L. parafarraginis (KU495926) retained activity even when heated to $121^{\circ} \mathrm{C}$. This is the typical finding with small molecular weight bacteriocins belonging to class $1(<5 \mathrm{kDa}$ ) and class 11 (up to $10 \mathrm{kDa}$ ) (Gulluce and Ozlem, 2013)

Exposure of CFS and active FPLC fractions to proteases such as pepsin, trypsin, $\alpha$-chymotrypsin and proteinase $\mathrm{K}$ resulted in no loss of activity. It has been reported that bacteriocins possessing a circular conformation (head-to-tail ligated cyclic antimicrobial peptide) such as circularin A, Microcin J25, gassercin A, and AS-48 were found to be highly resistant to digestion by certain proteases (Kemperman et al., 2003). This resistance may not be due to the absence of digestion sites for the enzymes but due to inaccessibility of recognition sites due to the three-dimensional structure of these circular peptides. Resistance to digestion by proteases can make circular peptides less susceptible to digestive enzymes from target bacteria and thus increase their activity range (Kemperman et al., 2003). Considering the broad range of pathogens inhibited by $L$. parafarraginis (KU495926) and the resistance of the partially purified peptide to digestion by proteases one cannot help but to consider the involvement of a circular peptide in its killing action.
All the bacteriocin structural genes detected in this study are associated with class 11 bacteriocins. These are non-lantibiotic bacteriocins, are further subdivided into three subgroups. Class 11a, are pediocin-like bacteriocin possessing strong antilisterial properties and a conserved $\mathrm{N}$ - terminal YGNGVXC consensus sequence in the mature peptide (Vaughan et al., 2003); Class11b constitutes heterodimeric bacteriocins which consists of two peptides. Full antimicrobial activity requires the presence of both peptides, and individual peptide yield little or no activity (Gulluce and Ozlem, 2013); Class 11c has been mentioned as consisting of hybrid bacteriocins that display characteristics of both class 11a and class 11b (Vaughan et al., 2003) as well as having head-to-tail cyclic peptide (Gulluce and Ozlem, 2013).

The acdT structural genes encodes for the bacteriocin acidocin. Lactobacillus acidophilus (TK8912) was the source for the acdT primers used in this study (Macwana and Muriana, 2012). The acidocin bacteriocin from this organism was purified (Tahara et al., 1992), as a single peptide with molecular weight of 5400 , composed of presumably 50 amino acids and showed bactericidal activity (Tahara et al., 1992). Acidocin has been mentioned as a class 11a bacteriocin, reported as possibly having a circular structure (Acedo et al., 2015; Deraz et al., 2006) and as been able to form oligomers which can dissociate into monomers (retained by $5 \mathrm{kDa}$ membrane) with higher activity (Chumchalova $\boldsymbol{e t}$ al., 2004)

The structural genes $p \ln C 8 A, \quad s a k T-\alpha$ and $s a k T-\beta$ all encode class $11 \mathrm{~b}$ bacteriocins. The genes sakT- $\alpha$ and $s a k T-\beta$ encodes the alpha and beta chains of sakacinT. SakacinT was first reported by Vaughn et al. 2003. It was found chromosomally encoded in Lactobacillus sakei 5. Its gene cluster included structural and immunity genes along with genes for sakacinT X but none for transport nor accessory protein; suggesting that a dedicated accessory protein is not required for its processing and transport. The peptides of sakacinT have been describes as two small, unmodified hydrophobic peptides requiring the activity of each other, though low activity can be exhibited by sakacinT- beta chain at high concentrations. The mature peptide size of sakacinT alpha and beta chain were stated as 51 and 43 respectively (Vaughan et al., 2003).

The bacteriocin plantaricin NC8 (PLNC8) was reported as a novel two-peptide bacteriocin by Maldonado et al 2008 isolated from Lactobacillus plantarum NC8. The bacteriocin constitute $\alpha(3,587 \mathrm{Da})$ and $\beta$ peptide $(4,000 \mathrm{Da})$ namely, PLNC $\alpha$ and PLNC $\beta$; encoded by the genes $p l N C 8 A$ and $p l N C 8 B$. In this study only genes for plNC8A were detected in L. parafarraginis (KU495926). The presence of both peptides is necessary for full plantaricin NC8 activity. In this study, a low trace scores of 15 was obtained for the DNA sequence for $p l N C 8 A$ The literature indicates that "very significant" are two direct repeats upstream of the PLNC8 operon. The presence of these repeats are believed to be involved in autoinduction acting as binding sites for response regulators of bacteriocin synthesis (Maldonado et al., 2003). The presence of these repeats however could have militated against proper synthesis of the sequences as within repetitive sequence the polymerase "slips" and with the currently available technologies there is no reliable method to make the enzyme faithfully reproduce repetitive regions (Genewiz).

Pairwise comparisons (NCBI-BLAST- Global alignment) of the DNA sequences

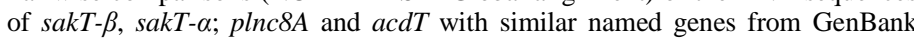
yielded $46,48,32$ and $46 \%$ identity respectively. These results suggest that there may be some degree of homology between the sequences. It was interesting that BLASTX analyses associated the conceptual translation products of the DNA sequences for the PCR amplicons with genes in the species $L$. parafarraginis This association further indirectly ascertained the identity of isolate A1 (KU495926) to this species. Based on the low e-values obtained for the putative gene products by BLASTX, it can be concluded that non-specific priming of these genes occurred instead of the targeted bacteriocin genes. This idea is however contrary to the findings of the in silico analyses done with the bacteriocin mining tool BAGEL3, which associated these sequences with putative bacteriocin structural genes/modified peptide. If the sequences obtained indeed encode for bacteriocins as BAGEL3 suggests, then it would lead one to conclude that there is some possible biological association between these bacteriocins and the putative gene products (Holliday junction branch migration protein RuvA, L-arabinose isomerase and glycosyl hydrolase family 2 sugar binding protein) predicted by BLASTX.

It has always been the conventional wisdom that bacteriocins from Gram-positive bacteria will not inhibit the growth of Gram-negative bacteria, but with increasing reported cases of this occurrence, this phenomenon may be more widely spread than is thought. This study demonstrated that an isolate from yogurt designated $L$. parafarraginis (KU495926) inhibited the growth of 14 MDR/ESBL Gram-negative bacteria and 11 other bacterial pathogens. The data suggests that the inhibitory action involved a bacteriocin-like substance associated with a peptide band $\sim 75 \mathrm{kDa}$. Of the four bacteriocin structural genes identified in L. parafarraginis (KU495926) it is believed that the most likely candidate that could have given rise to this peptide is the gene for acidocin, as it has been reported to give rise to cyclic peptides and as been able to form oligomers. These characteristics could explain the resistance to proteases, and the aggregation of the oligomers could have given rise to the large peptide band Efforts are however underway to purify and chemically identify this bacteriocinlike inhibitory agent. 


\section{CONCLUSION}

This is the first report of isolation and characterization of a L. parafarraginis species fom yogurt and its inhibitory action against MDR/ESBL Gram-negative bacteria and other pathogens. Multidrug-resistant bacteria are a threat to human security. Although there is currently no ideal alternative to mitigate the impact of these pathogens, this research showed that bacteriocins from LAB such as $L$. parafarraginis with broad spectrum antimicrobial activity maybe worth very serious consideration for use as antimicrobials in the clinical setting.

Acknowledgments: Gratitude must be expressed to Miss June Prout who submitted the MDR/ESBL Gram-negative bacteria for further study; to Dr. Winston Anderson who assisted in providing the resources for this project and Dr. Ayele Gugssa who assisted with resources as well as technical assistance.

\section{REFERENCES}

Abdulla, A. A. (2014). Optimization of DNA Extraction of Lactobacillus spp for Identification by tuf B gene-Based Polymerase Chain Reaction. J Biol Agric Healthc, Vol.4(No.8), 269-227. doi not found

Abee, T., Krockel, L., \& Hill, C. (1995). Bacteriocins: modes of action and potentials in food preservation and control of food poisoning. International $\begin{array}{llll}\text { Journal of Food } & \text { Microbiology, } & 28(2), & 169-185 .\end{array}$ doi:http://dx.doi.org/10.1016/0168-1605(95)00055-0

Acedo, J. Z., van Belkum, M. J., Lohans, C. T., McKay, R. T., Miskolzie, M., \& Vederas, J. C. (2015). Solution structure of acidocin B, a circular bacteriocin produced by Lactobacillus acidophilus M46. Applied and Environmental Microbiology, 81(8), 2910-2918. doi:http://dx.doi.org/10.1128/AEM.04265-14 Allen, A. D., Daley, P., Ayorinde, F. O., Gugssa, A., Anderson, W. A., \& Eribo, B. E. (2012). Characterization of medium chain length (R)-3-hydroxycarboxylic acids produced by Streptomyces sp. JM3 and the evaluation of their antimicrobia properties. World Journal of Microbiology \& Biotechnology, 28(9), 2791-2800. doi:http://dx.doi.org/10.1007/s11274-012-1089-Z

Awua, A. K., Doe, E. D., \& Agyare, R. (2012). Potential Bacterial Health Risk Posed to Consumers of Fresh Coconut (Cocos nucifer L.) Water. Food Nutr Sci, 03(08), 1136-1143. doi:http://dx.doi.org/10.4236/fns.2012.38149

Badel, S., Bernardi, T., \& Michaud, P. (2011). New perspectives for Lactobacilli exopolysaccharides. Biotechnology Advances, 29(1), 54-66. doi:http://dx.doi.org/10.1016/j.biotechadv.2010.08.011

Barreto-Vieira, D. F., \& Barth, O. M. (2015). Negative and Positive Staining in Transmission Electron Microscopy for Virus Diagnosis. In Microbiology in Agriculture and Human Health: InTech. doi not found

Beijerinick, M. W. (1901). Sur les ferments lactiques de l'industrie. Archives Néerlandaises des Sciences Exactes et Naturelles (Section 2), 6, 212-243. doi not found

Berney, M., Hammes, F., Bosshard, F., Weilenmann, H. U., \& Egli, T. (2007). Assessment and interpretation of bacterial viability by using the LIVE/DEAD BacLight Kit in combination with flow cytometry. Applied and Environmental Microbiology, 73(10), 3283-3290. doi:http://dx.doi.org/10.1128/AEM.02750-06 Chervaux, C., Ehrlich, S. D., \& Maguin, E. (2000). Physiological study of Lactobacillus delbrueckii subsp. bulgaricus strains in a novel chemically defined medium. Applied and Environmental Microbiology, 66(12), 5306-5311. doi:http://dx.doi.org/10.1128/AEM.66.12.5306-5311.2000

Chumchalova, J., Stiles, J., Josephsen, J., \& Plockova, M. (2004) Characterization and purification of acidocin $\mathrm{CH} 5$, a bacteriocin produced by Lactobacillus acidophilus CH5. Journal of Applied Microbiology, 96(5), 1082 1089. doi:http://dx.doi.org/10.1111/j.1365-2672.2004.02237.x

Cleveland, J., Montville, T. J., Nes, I. F., \& Chikindas, M. L. (2001) Bacteriocins: safe, natural antimicrobials for food preservation. International Journal of Food Microbiology, 71(1), 1-20. doi:http://dx.doi.org/10.1016/S0168 1605(01)00560-8

Daw, M. A., \& Falkiner, F. R. (1996). Bacteriocins: nature, function and structure. Micron, 27(6), 467-479. doi:http://dx.doi.org/10.1016/S09684328(96)00028-5

Deraz, S. F., Hedström, M., Karlsson, E. N., Linse, S., Khalil, A. A., \& Mattiasson, B. (2006). Production and physicochemical characterization of acidocin D20079, a bacteriocin produced by Lactobacillus acidophilus DSM 20079. World Journal of Microbiology and Biotechnology, 23(7), 911-921. doi:http://dx.doi.org/10.1007/s11274-006-9314-2

Dimitonova, S. P., Bakalov, B. V., Aleksandrova-Georgieva, R. N., \& Danova, S. T. (2008). Phenotypic and molecular identification of lactobacilli isolated from vaginal secretions. Journal of Microbiology, Immunology, and Infection. Wei Mian Yu Gan Ran Za Zhi, 41(6), 469-477. doi not found

Elshikh, M., Ahmed, S., Funston, S., Dunlop, P., McGaw, M., Marchant, R., \& Banat, I. M. (2016). Resazurin-based 96-well plate microdilution method for the determination of minimum inhibitory concentration of biosurfactants Biotechnology Letters, 38(6), 1015-1019. doi:http://dx.doi.org/10.1007/s10529016-2079-2

Endo, A., \& Okada, S. (2007). Lactobacillus farraginis sp. nov. and Lactobacillus parafarraginis sp. nov., heterofermentative lactobacilli isolated from a compost of distilled shochu residue. International Journal of Systematic $\begin{array}{lll}\text { and Evolutionary } & \text { Microbiology, } & \text { 57(4), 708-712. }\end{array}$ doi:http://dx.doi.org/doi:10.1099/ijs.0.64618-0

Genewiz. Solution guide for Sanger sequencing. Retrieved from https://clims4.genewiz.com/Common/TroubleShooting/en-US/Non-specific.pdf Gillespie, A. S., \& Elliott, E. (2005). Comparative advantages of imidazolesodium dodecyl sulfate-zinc reverse staining in polyacrylamide gels. Analytical Biochemistry, 345(1), 158-160. doi:http://dx.doi.org/10.1016/j.ab.2005.06.018 Gillor, O., Etzion, A., \& Riley, M. A. (2008). The dual role of bacteriocins as anti- and probiotics. Applied Microbiology and Biotechnology, 81(4), 591-606. doi:http://dx.doi.org/10.1007/s00253-008-1726-5

Goh, H. F., \& Philip, K. (2015). Purification and characterization of bacteriocin produced by Weissella confusa A3 of dairy origin. PloS One, 10(10), e0140434. doi:http://dx.doi.org/10.1371/journal.pone.0140434

Gulluce, M. M. K., \& Ozlem, B. (2013). Bacteriocins: Promising Natural Antimicrobials. Microbial pathogens and strategies for combating them. Science, Technology and Education, 2, 1016-1027. doi not found

Heng, N. C., Wescombe, P. A., Burton, J. P., Jack, R. W., \& Tagg, J. R. (2007) The diversity of bacteriocins in Gram-positive bacteria. In Bacteriocins (pp. 45 92): Springer. Retrieved from https://link.springer.com/chapter/10.1007\%2F978 3-540-36604-1_4. doi:http://dx.doi.org/10.1007/978-3-540-36604-1_4

Holt, J. G., Krieg, N. R., Sneath, P. H. A., Staley, J. T., \& Williams, S. T. (1994) Bergey's Manual of Determinative Bacteriology (W. R. Hensyl Ed. 9th ed.). Baltimore, Maryland 21202, USA: Williams \& Wilkins. doi not found

Iyapparaj, P., Maruthiah, T., Ramasubburayan, R., Prakash, S., Kumar, C., Immanuel, G., \& Palavesam, A. (2013). Optimization of bacteriocin production by Lactobacillus sp. MSU3IR against shrimp bacterial pathogens. Aquat Biosyst, 9(1), 12. doi:http://dx.doi.org/10.1186/2046-9063-9-12

Jay, J. M., Loessner, M. J., \& Golden, D. A. (2008). Modern food microbiology (7th ed.). New York. USA.: Springer Science \& Business Media. doi not found Johanningsmeier, S. (2011). PhD Dissertation. Raleigh,North Carolina. Biochemical Characterization of Fermented Cucumber Spoilage using Nontargeted, Comprehensive, Two-dimensional Gas Chromatography-Time-ofFlight Mass Spectrometry: Anaerobic Lactic Acid Utilization by Lactic Acid Bacteria. doi not found

Joshi, K. V., Sharma, S., \& Rana, N. S. (2006). Production, Purification, Stability and Efficacy of Bacteriocin from Isolates of Natural Lactic Acid Fermentation of Vegetables. Food Technology and Biotechnology, 44(3), 435-439. doi not found Kazemipoor, M., Radzi, C. W. J. M., Begum, K., \& Yaze, I. (2012). Screening of antibacterial activity of lactic acid bacteria isolated from fermented vegetables against food borne pathogens. Arch Sci, Vol.65, Issue 6( ). doi not found Kemperman, R., Kuipers, A., Karsens, H., Nauta, A., Kuipers, O., \& Kok, J. (2003). Identification and characterization of two novel clostridial bacteriocins, circularin A and closticin 574. Applied and Environmental Microbiology, 69(3), 1589-1597. doi:http://dx.doi.org/10.1128/AEM.69.3.1589-1597.2003

Klaenhammer, T. R. (1988). Bacteriocins of lactic acid bacteria. Biochimie, 70(3), 337-349. doi:http://dx.doi.org/10.1016/0300-9084(88)90206-4

Kwon, D.-Y., Koo, M.-S., Ryoo, C.-R., Kang, C.-H., Min, K.-H., \& Kim, W.-J (2002). Bacteriocin produced by Pediococcus sp. in kimchi and its characteristics. J. Microbiol. Biotechnol., 12(1), 96-105. doi not found

Lee, C. M., Sieo, C. C., Wong, C. M. V. L., Abdullah, N., \& Ho, Y. W. (2008). Sequence analysis of 16S rRNA gene and 16S-23S rRNA gene intergenic spacer region for differentiation of probiotics Lactobacillus strains isolated from the gastrointestinal tract of chicken. Annals of Microbiology, 58(1), 133-140 doi:http://dx.doi.org/10.1007/bf03179457

Lee, H. H., Lee, S. H., Lee, S. J., \& Kim, M. H. (2013). Lactobacillus parafarraginis strain having functions of deodorization activity and purification of water in eel farm, and use thereof. In: Google Patents .Publication number WO2013147426 A1.doi not found

Lin, Z., Liu, Z., Yang, R., Zou, Y., Wan, D., Chen, J., . . Liu, F. (2013). WholeGenome Sequencing of Lactobacillus shenzhenensis Strain LY-73(T). Genome Announcements, $1(6)$,

e00972-00913.

doi:http://dx.doi.org/10.1128/genomeA.00972-13

Liu, Q. H., Yang, F. Y., Zhang, J. G., \& Shao, T. (2014). Characteristics of Lactobacillus parafarraginis $\mathrm{ZH} 1$ and its role in improving the aerobic stability of silages. Journal of Applied Microbiology, 117(2), 405-416. doi:http://dx.doi.org/10.1111/jam.12530

Macwana, S. J., \& Muriana, P. M. (2012). A 'bacteriocin PCR array' for identification of bacteriocin-related structural genes in lactic acid bacteria. Journal of Microbiological Methods, $88(2), \quad 197-204$ doi:http://dx.doi.org/10.1016/j.mimet.2011.11.008

Madigan, M., Martinko, J., Stahl, D., \& Clark, D. (2012). Biology of Microorganisms. In Biology of Microorganisms (13th ed.). San Francisco U.S.A.: Benjamin Cummings. doi not found

Maldonado, A., Ruiz-Barba, J. L., \& Jiménez-Díaz, R. (2003). Purification and genetic characterization of plantaricin NC8, a novel coculture-inducible twopeptide bacteriocin from Lactobacillus plantarum NC8. Applied and Environmental Microbiology, 69(1), 383-389. doi:http://dx.doi.org/10.1128/AEM.69.1.383-389.2003 
McFarland, J. (1907). The nephelometer: an instrument for estimating the number of bacteria in suspensions used for calculating the opsonic index and for vaccines. Journal of the American Medical Association, XLIX(14), 1176-1178. doi:http://dx.doi.org/10.1001/jama.1907.25320140022001f

McNabb, A., Shuttleworth, R., Behme, R., \& Colby, W. D. (1997). Fatty acid characterization of rapidly growing pathogenic aerobic actinomycetes as a means of identification. Journal of Clinical Microbiology, 35(6), 1361-1368. doi not found

Mirhosseini, M., Iraj, N., Giti, E., \& Manouchehr, T. (2008). Culture-Dependent and Culture-Independent Qualitative Analysis of

Dairy Products for Bacteriocin Production by Lactic Acid Bacteria. World Appl Sci J, 5(1), 20-24. doi not found

Mlalazi, M., Winslow, A. R., Beaubrun, J. J.-G., \& Eribo, B. E. (2011). Occurrence of Pediocin PA-1AcH-Like Bacteriocin in Native Non-starter Lactobacillus casei, Lactobacillus paracasei and Lactobacillus rhamnosus from retail Ched.pdf. Internet Journal of Food Safety, 13, 325-331. doi not found Moraes, P. M., Perin, L. M., Silva Júnior, A., \& Nero, L. A. (2013). Comparison of phenotypic and molecular tests to identify lactic acid bacteria. Brazilian Journal of Microbiology, 44(1), 109-112. doi not found

Moretro, T., Hagen, B. F., \& Axelsson, L. (1998). A new, completely defined medium for meat lactobacilli. Journal of Applied Microbiology, 85(4), 715-722. doi:http://dx.doi.org/10.1111/j.1365-2672.1998.00583.x

Muller, D. M., Carrasco, M. S., Tonarelli, G. G., \& Simonetta, A. C. (2009) Characterization and purification of a new bacteriocin with a broad inhibitory spectrum produced by Lactobacillus plantarum lp 31 strain isolated from dryfermented sausage. Journal of Applied Microbiology, 106(6), 2031-2040. doi:http://dx.doi.org/10.1111/j.1365-2672.2009.04173.x

Nigatu, A. (2000). Evaluation of numerical analyses of RAPD and API $50 \mathrm{CH}$ patterns to differentiate Lactobacillus plantarum, Lact. fermentum, Lact. rhamnosus, Lact. sake, Lact. parabuchneri, Lact. gallinarum, Lact. casei, Weissella minor and related taxa isolated from kocho and tef. Journal of Applied Microbiology, 89(6), 969-978. doi:http://dx.doi.org/10.1046/j.13652672.2000.01202.x

Ongol, M. P. (2012). Lactic Acid Bacteria in Health and Disease. Rwanda Journal of Health Sciences, 1(1)

Parada, J. L., Caron, C. R., Medeiros, A. B. P., \& Soccol, C. R. (2007). Bacteriocins from lactic acid bacteria: purification, properties and use as biopreservatives. Braz Arch Biol Technol, 50(3), 512-542. doi:http://dx.doi.org/10.1590/S1516-89132007000300018

Pingitore, E. V., Salvucci, E., Sesma, F., \& E., N.-M. M. (2007). Different strategies for purification of antimicrobial peptides from Lactic Acid Bacteria (LAB). Foramatex 2007. doi not found

Riley, M., \& Gillor, O. (2007). Research and Applications in Bacteriocins (G. O. Riley A Magaret Ed.): Horizon Bioscience.

Riley, M. A., \& Gordon, D. M. (1999). The ecological role of bacteriocins in bacterial competition. Trends in Microbiology, 7(3), 129-133.

Salvetti, E., Torriani, S., \& Felis, G. E. (2012). The Genus Lactobacillus: A Taxonomic Update. Probiotics Antimico., 4(4), 217-226. doi:http://dx.doi.org/10.1007/s12602-012-9117-8

Schagger, H. (2006). Tricine-SDS-PAGE. Nature Protocols, 1(1), 16-22. doi:http://dx.doi.org/10.1038/nprot.2006.4

Sharma, N., \& Neha., G. (2008). Antibacterial activity and characterization of bacteriocin of Bacillus mycoides. Indian Journal of Microbiology, Vol. 7, 117 121. doi not found

Singh, V., Rana, R. K., \& Singhal, R. (2013). Analysis of repeated measurement data in the clinical trials. Journal of Ayurveda and Integrative Medicine, 4(2), 77 81. doi:http://dx.doi.org/10.4103/0975-9476.113872

Sun, Z., Harris, H. M. B., McCann, A., Guo, C., Argimón, S., Zhang, W., . . . O'Toole, P. W. (2015). Expanding the biotechnology potential of lactobacilli through comparative genomics of 213 strains and associated genera. Nat Commun, 6, 8322. doi:http://dx.doi.org/10.1038/ncomms9322

Tahara, T., Kanatani, K., Yoshida, K., Miura, H., Sakamoto, M., \& Oshimura, M (1992). Purification and Some Properties of Acidocin 8912, a Novel Bacteriocin Produced by Lactobacillus acidophilus TK8912. Bioscience, Biotechnology, and Biochemistry, 56(8), 1212-1215. doi:http://dx.doi.org/10.1271/bbb.56.1212

Tannock, G. W. (2004). A special fondness for lactobacilli. J Appl Environ Microbiol, 70(6), 3189-3194. doi:http://dx.doi.org/10.1128/AEM.70.6.3189$\underline{3194.2004}$

Todorov, S. D., \& Dicks, L. M. T. (2005). Lactobacillus plantarum isolated from molasses produces bacteriocins active against Gram-negative bacteria. Enzyme and Microbial Technology, 36(2-3), 318-326 doi:http://dx.doi.org/10.1016/j.enzmictec.2004.09.009

van Heel, A. J., de Jong, A., Montalban-Lopez, M., Kok, J., \& Kuipers, O. P. (2013). BAGEL3: Automated identification of genes encoding bacteriocins and (non-)bactericidal posttranslationally modified peptides. Nucleic Acids Research, 41(Web Server issue), W448-453. doi:http://dx.doi.org/10.1093/nar/gkt391 van Reenen, C. A., Dicks, L. M., \& Chikindas, M. L. (1998). Isolation, purification and partial characterization of plantaricin 423 , a bacteriocin produced by Lactobacillus plantarum. Journal of Applied Microbiology, 84(6), 1131-1137. doi:http://dx.doi.org/10.1046/j.1365-2672.1998.00451.x
Vaughan, A., Eijsink, V. G., \& Van Sinderen, D. (2003). Functional characterization of a composite bacteriocin locus from malt isolate Lactobacillus sakei 5. Applied and Environmental Microbiology, 69(12), 7194-7203. doi:http://dx.doi.org/10.1128/AEM.69.12.7194-7203.2003

Walsh, C. J., Guinane, C. M., Hill, C., Ross, R. P., O’Toole, P. W., \& Cotter, P. D. (2015). In silico identification of bacteriocin gene clusters in the gastrointestinal tract, based on the Human Microbiome Project's reference $\begin{array}{llll}\text { genome database. } & B M C & \text { Microbiology, } & 15(1),\end{array}$ doi:http://dx.doi.org/10.1186/s12866-015-0515-4

Zacharof, M. P., \& Lovitt, R. W. (2012). Bacteriocins Produced by Lactic Acid Bacteria a Review Article. APCBEE Procedia, 2, 50-56 doi:http://dx.doi.org/10.1016/j.apcbee.2012.06.010 